\title{
34. LATE CRETACEOUS AND PALEOCENE BENTHIC FORAMINIFERS FROM DEEP SEA DRILLING PROJECT SITE 516, RIO GRANDE RISE, WESTERN SOUTH ATLANTIC OCEAN ${ }^{1}$
}

\author{
Donald H. Dailey, Cities Service Research, Tulsa, Oklahoma
}

\begin{abstract}
Benthic foraminifers of the Coniacian-Santonian through the Paleocene were recovered from a continuous pelagic carbonate section from Hole 516F on the Rio Grande Rise. Sixty-five genera and 153 species have been identified, most of which have been reported from other localities. Bathyal depths are reflected in the benthic assemblages dominated by gavelinellids (Gavelinella beccariiformis, G. velascoensis), Nuttallides truempyi, and various gyroidinids and buliminids. Rapid subsidence during the Coniacian-Santonian from nearshore to upper to middle bathyal depths was followed by much reduced subsidence, with the Campanian-Paleocene interval accumulating at middle bathyal to lower bathyal depths.

A census study based on detailed sampling reveals major changes in benthic faunal composition at the Cretaceous/ Tertiary boundary transition. It was a time of rapid turnover, with the extinctions of numerous species and the introduction of many new species. Overall, species diversity decreases about $20 \%$, and approximately one-third of latest Maestrichtian species do not survive to the end of the Cretaceous. This shift indicates a significant environmental change in the deep sea, the precise nature of which is not apparent from the foraminifers or their enclosing sediments.
\end{abstract}

\section{INTRODUCTION}

Of the four sites drilled during Leg 72, Upper Cretaceous and Paleocene sediments were encountered only at Site 516. One of the objectives of this site was to investigate the early evolution of the Rio Grande Rise by drilling through the earliest deposited sediments and into the basement. Three previous attempts to reach the oldest sediments and basement, i.e., Leg 3, Sites 21 and 22 (Maxwell, Von Herzen, et al., 1970a, b), and Leg 39, Site 357 (Perch-Nielsen, Supko, et al., 1977), bottomed in Campanian, Oligocene, and Santonian sediments, respectively. Hole $516 \mathrm{~F}$, situated on the northeast flank of the Rio Grande Rise at $30^{\circ} 16.59^{\prime} \mathrm{S}, 35^{\circ} 17.11^{\prime} \mathrm{W}$, at a water depth of $1313 \mathrm{~m}$ (Fig. 1), was successfully rotarydrilled with continuous coring from 169 to $1270.6 \mathrm{~m}$. We encountered basement at $1252.6 \mathrm{~m}$ and, below the $900 \mathrm{~m}$ horizon, an essentially complete Upper Cretaceous (Coniacian/Santonian-Maestrichtian) through $\mathrm{Pa}$ leocene succession with an intact Cretaceous/Tertiary boundary. This report records the Upper CretaceousPaleocene benthic foraminifers from this site.

The sedimentary section is predominantly a pelagic carbonate succession (Fig. 2). A high percentage of recovery was achieved, except for the lowermost $50 \mathrm{~m}$, where, on the average, only about $35 \%$ of the penetrated section was retrieved. No significant hiatuses or sediment mixing could be recognized within this succession.

Age correlations are based on planktonic foraminifers, coccoliths, and magnetic reversals reported from Site 516 and described in separate chapters of this volume by Pujol, Weiss, and Hamilton and Suzyumov.

\footnotetext{
${ }^{1}$ Barker, P. F., Carlson, R. L., Johnson, D. A., et al., Init. Repts. DSDP, 72: Washington (U.S. Govt. Printing Office).
}

Data on the benthic fauna and the stratigraphic occurrences of species are given in Figures 3 through 5 and Appendix 1. Most of the common species are illustrated on Plates 1 through 10.

Sixty-five genera and 153 species have been identified. The foraminiferal fauna, in general, bears a close resemblance to deep-water faunas of distant regions. The Upper Cretaceous assemblages include species reported from California, the U.S. Gulf Coast, the Tampico Embayment of Mexico, and western and eastern Europe; those of the Paleocene have greatest affinities with faunas of the Tampico Embayment, Trinidad, Austria, and the Caucasus region of the Soviet Union. A preponderance of species in the Site 516 fauna have been recognized at other DSDP sites within the South Atlantic region. These include Sites 327, 329, and 330 of Leg 36, from the Falkland Plateau; Sites 355-358 of Leg 39 , off southeast Brazil; and Sites 361,363 , and 364 of Leg 40, off southwest Africa. The reader is referred to Beckman (1972, 1978), Proto Decima and Bolli (1978), Sliter (1976, 1977a, b), Tjalsma (1976), and Tjalsma and Lohmann (in press) for more extensive commentaries on the affinities of South Atlantic Upper Cretaceous and Paleocene benthics with other reported contemporaneous faunas.

\section{METHODS}

Both freed specimens from disaggregated samples and thin sections cut from indurated limestone were used. However, only freed specimens were utilized in the sample census. The census is based on

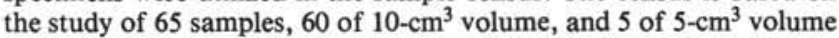
from the Cretaceous/Tertiary boundary transition interval. Only specimens greater than $150 \mu \mathrm{m}$ in diameter were examined. Numbers of benthic specimens per sample fluctuate from as few as 126 individuals to more than 2000; their abundance varies from an estimated 3 to $100 \%$ relative to the planktonic element. No relationship between lithology and abundance or diversity of species is apparent.

A slight majority of the assemblages consist of the 300 or more individuals necessary for a statistically valid representation of the fauna 


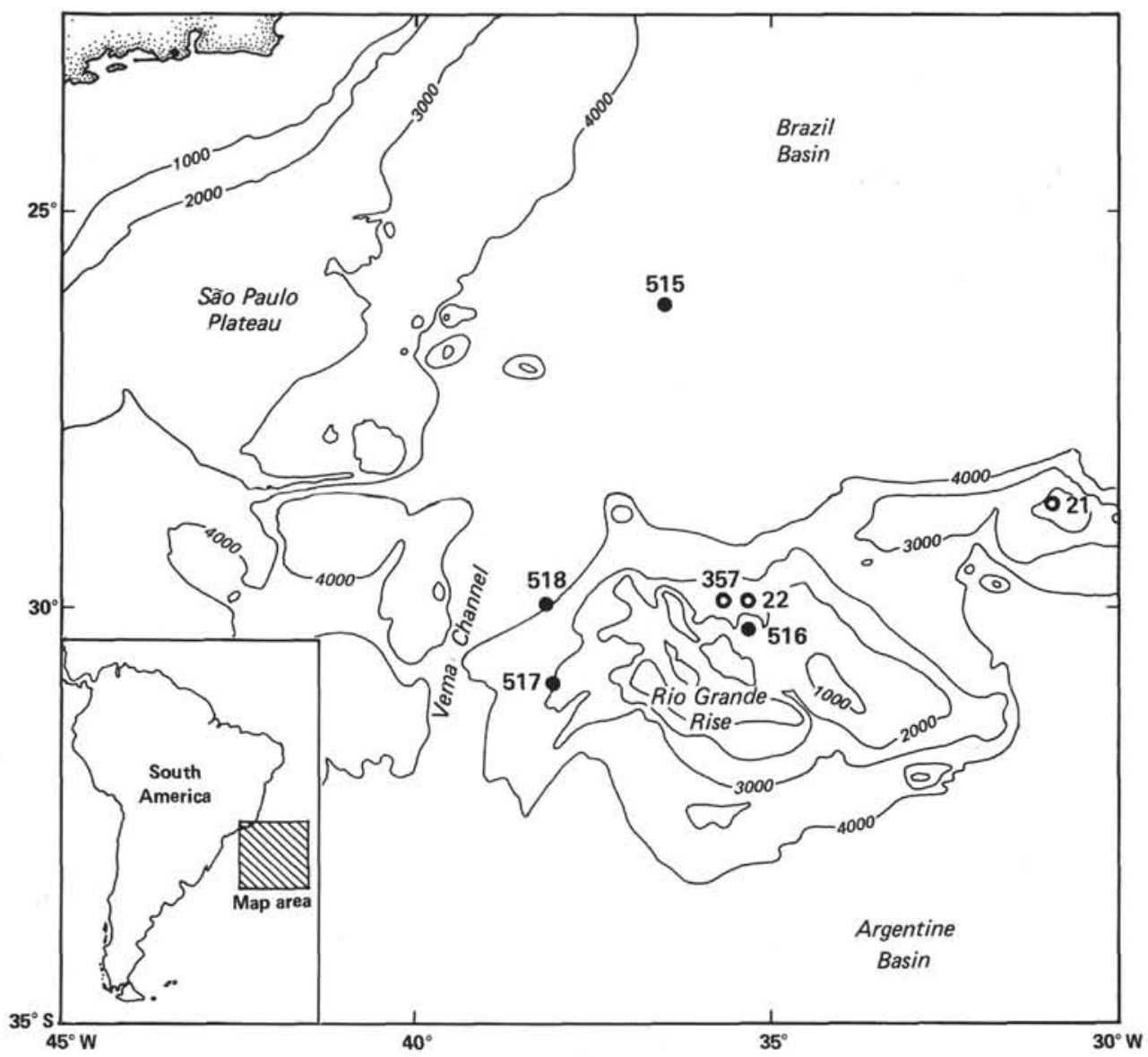

Figure 1. Location of Site 516 of Leg 72, Sites 21 and 22 of Leg 3, and Site 357 of Leg 39, on the Rio Grande Rise, off the eastern coast of South America. Depth contours are shown in meters.

(Douglas, 1973; Streeter, 1973). Fewer individuals occur in the remaining assemblages, indicating that the survey has under-represented the rarer species occurring in these samples and incompletely documented their stratigraphic ranges. The maximum number of individuals counted in any sample was approximately 600 . The richer assemblages generally were reduced by splitting to a more convenient size.

\section{ABUNDANCE AND PRESERVATION}

Benthic foraminifers are common to abundant in all but the lowermost few meters of section (down to Core $516 \mathrm{~F}-124$, Section 1). Preservation is generally moderate but deteriorates below $1087 \mathrm{~m}$ (Core 516F-105) because of increasing recrystallization. Foraminifers could not be extracted from the highly recrystallized dolomitic limestone intervals between 1155 and $1172 \mathrm{~m}$ (Cores $516 \mathrm{~F}-114$ and $516 \mathrm{~F}-115$ ) or below $1203 \mathrm{~m}$ (Cores 516F119 to $516 \mathrm{~F}-125$ ).

The number of benthic species per sample varies from 15 to 43 , averaging 28 for the Cretaceous and 29 for the Paleocene, a degree of diversity much less than would be expected from comparison with well-preserved Recent and fossil deep-sea faunas. This, together with the common occurrence of numbers of broken and surfacedamaged individuals, indicates some undetermined loss by selective dissolution.

Associated biogenic material includes Inoceramus shell fragments and prisms, abundant below $1150 \mathrm{~m}$ and usually present as high as $1080 \mathrm{~m}$, and fecal pellets in flood proportions between 1087 and $1225 \mathrm{~m}$. Rare ostracodes and echinoderm spine fragments occur at a few horizons.

\section{FORAMINIFERAL ASSEMBLAGES}

\section{Upper Cretaceous}

Santonian-Maestrichtian benthic species were recovered above the $1200 \mathrm{~m}$ horizon. Cretaceous benthic assemblages are dominated by the Cassidulinacea; the genera Gavelinella and Gyroidinoides are especially prominent, together with fewer Osangularia and Pullenia (Fig. 3 and 4). Somewhat less important, both in abundance and variety, are the Discorbinacea represented by Nuttallides and Nuttallinella, and the Buliminacea, represented primarily by Praebulimina. The Nodosariacea occur in persistent but low numbers, whereas the agglutinated types, although occasionally numerous, develop little diversity. Least prominent are the Orbitoidacea represented by modest numbers of Neoeponides.

Especially conspicuous are several long-ranging cosmopolitan species that occur in both the Upper Cretaceous and Paleocene intervals. These include, among others: Gavelinella beccariiformis, G. hyphalus, G. velascoensis, Gyroidinoides globosus, Lenticulina macrodisca, and Nuttallides truempyi. The most abundantly 


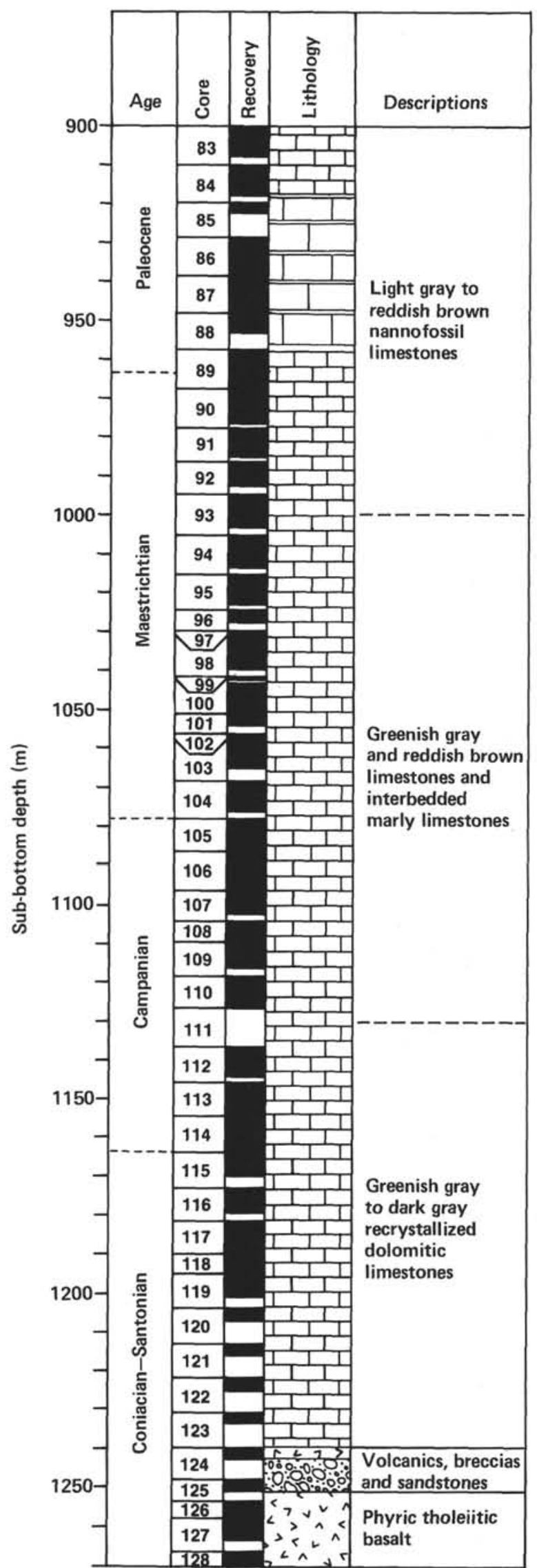

Figure 2. Upper Cretaceous-Paleocene stratigraphy of Hole 516F. occurring species that are more or less confined to Cretaceous strata are: Gavelinella stephensoni, Gyroidinoides beisseli, G. goudkoffi, G. nitidus, Nuttallinella florealis, and Praebulimina reussi.

Santonian assemblages (Core 516F-116, Section 3 to Core 516F-119, Section 3) consist of a relatively lowdiversity benthic element. Bolivinoides strigillatus, Gyroidinoides praeglobosus, and Globorotalites multiseptus appear to be restricted to this interval.

Campanian and Maestrichtian assemblages are characterized by increased species diversity over that of the Santonian fauna. Species diversity continues to increase until the late Maestrichtian, when a significant reduction in variety occurs and many characteristic Cretaceous species drop out. The majority of species make their first appearance in the Campanian, but none appear to be restricted to this age. Characteristic species of the Maestrichtian are B. draco draco, Coryphostoma incrassata, Eouvigerina americana, and $P$. triangularis.

\section{Paleocene}

Paleocene benthic assemblages compare closely with the underlying Cretaceous fauna at the suprageneric level but are otherwise distinguished by reduced diversity and by some turnover in genera and species. Assemblages are dominated by large populations of Cibicidoides, Gavelinella, and Nuttallides, together with fewer Anomalinoides and Gyroidinoides. Genera present only as accessory elements in the Cretaceous, such as Oridorsalis and Pullenia, occur in greater abundance. Approximately $67 \%$ of the species present in the upper Maestrichtian continue on into the Paleocene; the cosmopolitan types, in general, maintain their dominance.

Many new species first appear in the lowest Paleocene; the most prominent are Anomalinoides welleri, Dorothia beloides, $D$. cubensis, and Bulimina trinitatensis (which is confined to this interval). The remainder of the Paleocene, on the other hand, was a comparatively stable period. Some extinctions occurred but were compensated for by an equivalent number of first appearances. New species introduced at this time that immediately assumed a dominant position are Cibicidoides pseudoperlucidus and $B$. velascoensis.

The latest Paleocene was characterized by a sudden increase in extinctions. The genus Bolivinoides, together with the remaining species with origins in the Late Cretaceous (except Nuttallides truempyi, Nonion havanense, and Oridorsalis umbonatus), disappeared. The result was a low-diversity fauna dominated by these species and by Cibicidoides. A similar reduction has been documented in Trinidad (Beckman, 1960), Austria (Hillebrandt, 1962), and at several Atlantic Ocean DSDP sites (Tjalsma and Lohmann, in press).

\section{PALEOBATHYMETRY}

Depth of deposition interpretations have been inferred from the character of the benthic assemblages, planktonic/benthic ratios, and associated fossils and lithologic types. The marine benthic depth zones used in the following discussion are neritic $(0-200 \mathrm{~m})$, upper bathyal 


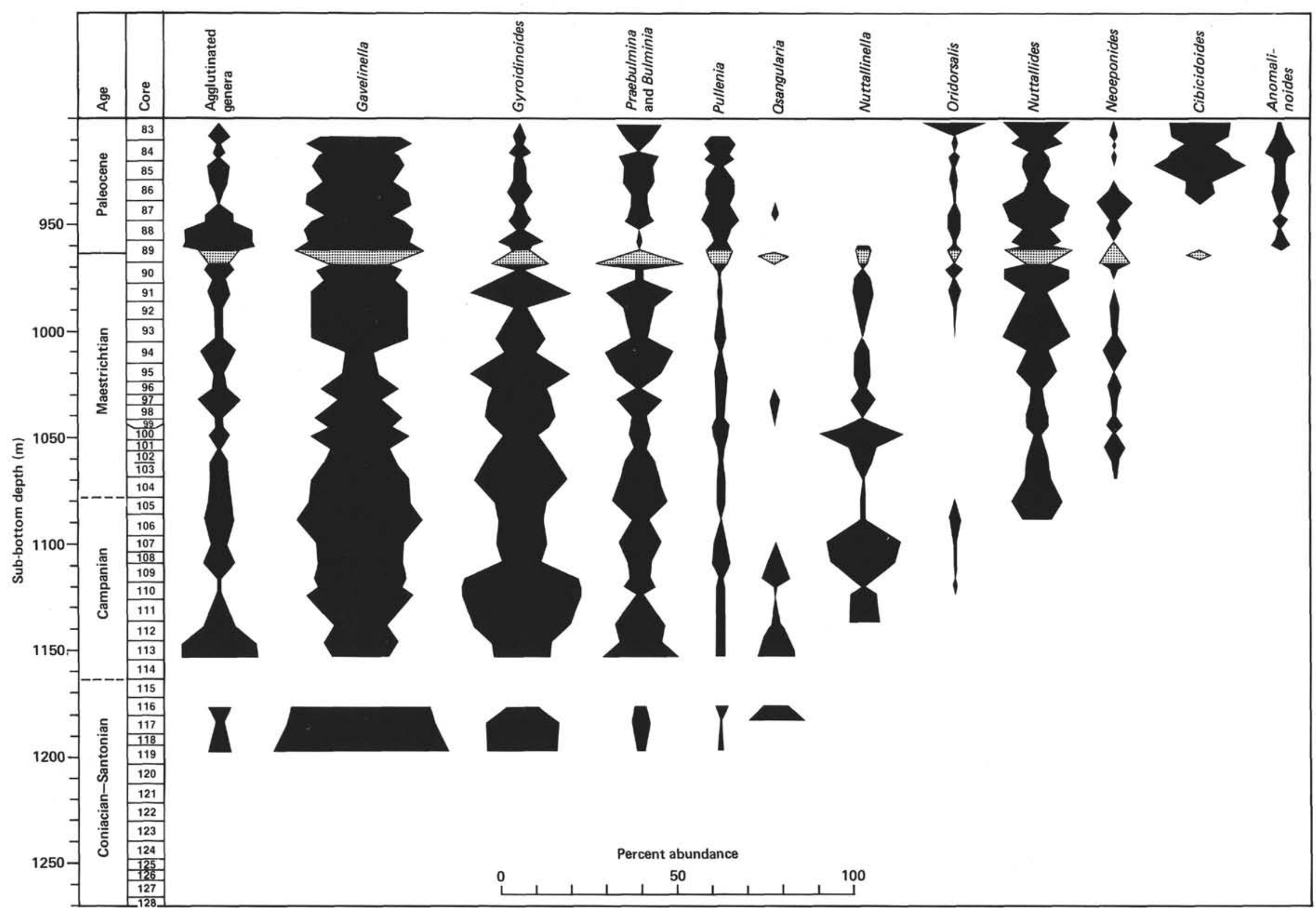

Figure 3. Frequency distribution of selected benthic foraminiferal taxa from Coniacian-Santonian to Paleocene of Hole 516F. See Figure 4 for distribution through stipled interval in Core $516 \mathrm{~F}-89$. 


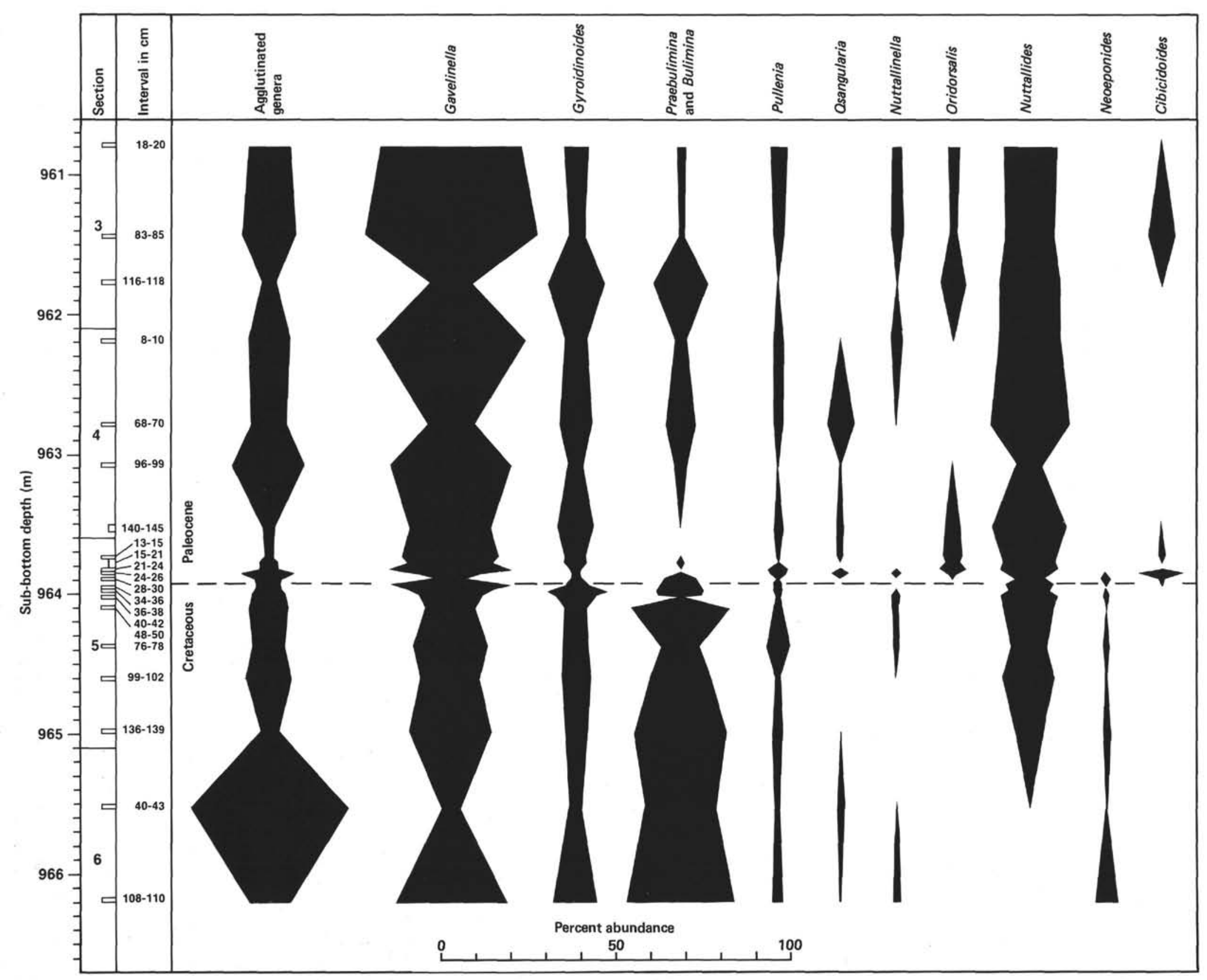


(200-500 m), middle bathyal (500-1500 m), lower bathyal $(1500-2500 \mathrm{~m})$, and abyssal $(>2500 \mathrm{~m})$.

Thin sections from several Coniacian-Santonian horizons below $1200 \mathrm{~m}$ (Cores $121-126$ in Hole 516F) reveal planktonic foraminifers in Core $516 \mathrm{~F}-124$, Section 1 and benthics in Core 516F-126, Section 1. Milliman (this volume) reports carbonate sediment dominated by shallow water biogenic particles (coralline algae, benthic foraminifers, mega-invertebrate fragments), from fractures in the volcanic basement. He interpreted this deposit as having accumulated at shallow depths, possibly $<20 \mathrm{~m}$. The stratigraphically lowest horizon examined for foraminifers (Sample 516F-125-2, 15-17 cm) includes rare indeterminate miliolids, ophthalmidiids?, and ostracodes in a well-washed and sorted skeletal grainstone. This material indicates a high-energy environment with water depths probably not deeper than $20 \mathrm{~m}$.

A coarse-grained skeletal packstone layer in Core $516 \mathrm{~F} 124$, Section 1, consisting primarily of large Inoceramus shell fragments, calcispheres, and lesser amounts of coralline algae and pellets in a heavily iron-stained mud matrix, includes the following foraminifers: verneuilinids, miliolids, indeterminate rotaliid types, and heterohelicid and globotruncanid planktonics. These data imply a more open marine-shelf sea environment.

Cores $516 \mathrm{~F}-121$ through $516 \mathrm{~F}-123$ show further deepening to outer neritic or shallow bathyal depths on the basis of alternating layers of claystone and fine-grained skeletal wackestone-packstone in a claystone matrix, in which radiolarians are abundant and Inoceramus prisms and shell fragments, ostracodes, and tiny heterohelicid and hedbergellid planktonic foraminifers are common.

The remainder of the Upper Cretaceous and Paleocene stratigraphic sequence is characterized by a welldeveloped foraminiferal fauna of bathyal character. Upper Cretaceous assemblages bear close resemblance to bathyal benthic successions of California (Sliter, 1968; Sliter and Baker, 1972) and the South Atlantic (Sliter, 1977).

The Santonian fauna (Cores $516 \mathrm{~F}-116$ to $516 \mathrm{~F}-119$ ) is characterized by a great abundance of the deep-water indicator Gavelinella beccariiformis; also present in fewer numbers are Globorotalites multiseptus, Gyroidinoides praeglobosus, Osangularia cordieriana, and Lenticulina muensteri. This fauna represents upper to middle bathyal depths, and includes no shallower indicators. The abundant planktonic element (planktonic/benthic ratio 10:1) is in keeping with this interpretation (Fig. 5). Preservation ranges from moderate to poor. The modest faunal diversity (15-19 species) and high dominance of the durable Cassidulinacea seem to be the results of selective dissolution.

In the Campanian and Maestrichtian (Sample 516F$89-5,30 \mathrm{~cm}$ through Sample 516F-113-6, 89-91 cm), benthic assemblages are more diverse and moderately well preserved. They contain large populations of Gavelinella ( $G$. beccariiformis, $G$. velascoensis), Nuttallides truempyi, Praebulimina reussi, and diverse gyroidinids and agglutinated species. The foraminiferal fauna develops a high planktonic/benthic ratio in the Maestrichti- an, with the planktonic element making up $95 \%$ or more of the assemblages. Overall, this fauna is characteristic of middle bathyal to shallow lower bathyal depths.

Paleocene assemblages (Sample 516F-83-2, 28-30 cm through Sample 516F-89-5, $30 \mathrm{~cm}$ ) compare closely with early Tertiary deep-sea faunas from the western North Atlantic and South Atlantic DSDP sites recently studied by Tjalsma and Lohmann (in press). The assemblages are dominated by a deep-water association of, among others, Cibicidoides pseudoperlucidus, Gavelinella beccariiformis, and Nuttallides truempyi. Wide fluctuations in abundances, probably signifying ecologic instability in the shallower layers of the water column, characterize the earliest Paleocene planktonic element. Planktonic species are generally very abundant throughout the remainder of the Paleocene succession. The pelagic character of the fauna, together with the benthic deep-bathymetric indicators, indicate that, during the Paleocene, lower bathyal depths on the order of $1500-2000 \mathrm{~m}$ prevailed at Site 516 .

\section{Cretaceous/Tertiary Boundary}

The stratigraphic section at Site 516 includes a continuous deposition sequence spanning the Cretaceous/ Tertiary boundary. Well-preserved foraminifers are present throughout the boundary transition interval, providing the opportunity to study in detail the stratigraphic distribution of benthic species across this important time-stratigraphic horizon.

Two investigations into the distribution of benthic foraminifers across the boundary have been carried out. Both involved bathyal faunas recovered from incomplete sections that lack an intact boundary. Beckman (1960) showed that benthics occurring in the Upper Cretaceous Guayaguayare and Paleocene Lizard Springs formations in southern Trinidad change relatively little across the boundary; many relic species from the Cretaceous extend into the Paleocene. Webb (1973) determined a benthic extinction rate of $18 \%$ for the Trinidad Maestrichtian benthic fauna and, in addition, reported a benthic level of extinction of $54 \%$ for Upper Cretaceous taxa across the Cretaceous/Tertiary boundary at Site 208, Lord Howe Rise, Tasman Sea.

Upper Maestrichtian to lower Paleocene sediments of Site 516 consist of nannofossil limestone with some interbedded marly claystone. The Cretaceous/Tertiary transition between 963.7-964.2 m (Sample 516F-89-5, 10-50 $\mathrm{cm}$ ) is characterized by a change at $35 \mathrm{~cm}$ from light gray to light reddish brown nannofossil limestone and by a sharp increase in interbedded dark gray mudstone. The mudstone occurs as angular to subhorizontal laminae and thin layers; some layers have developed minor rippling. Soft sediment deformation and minor intraformation fractures also are evident above the $25 \mathrm{~cm}$ horizon. Reworked Maestrichtian foraminifers occur through the transition interval above the $38 \mathrm{~cm}$ horizon. The most obviously displaced benthic species are indicated in the Appendix at the end of the chapter. Overall, these features suggest deposition in an unstable environment, with admixture of material from shallower horizons. 


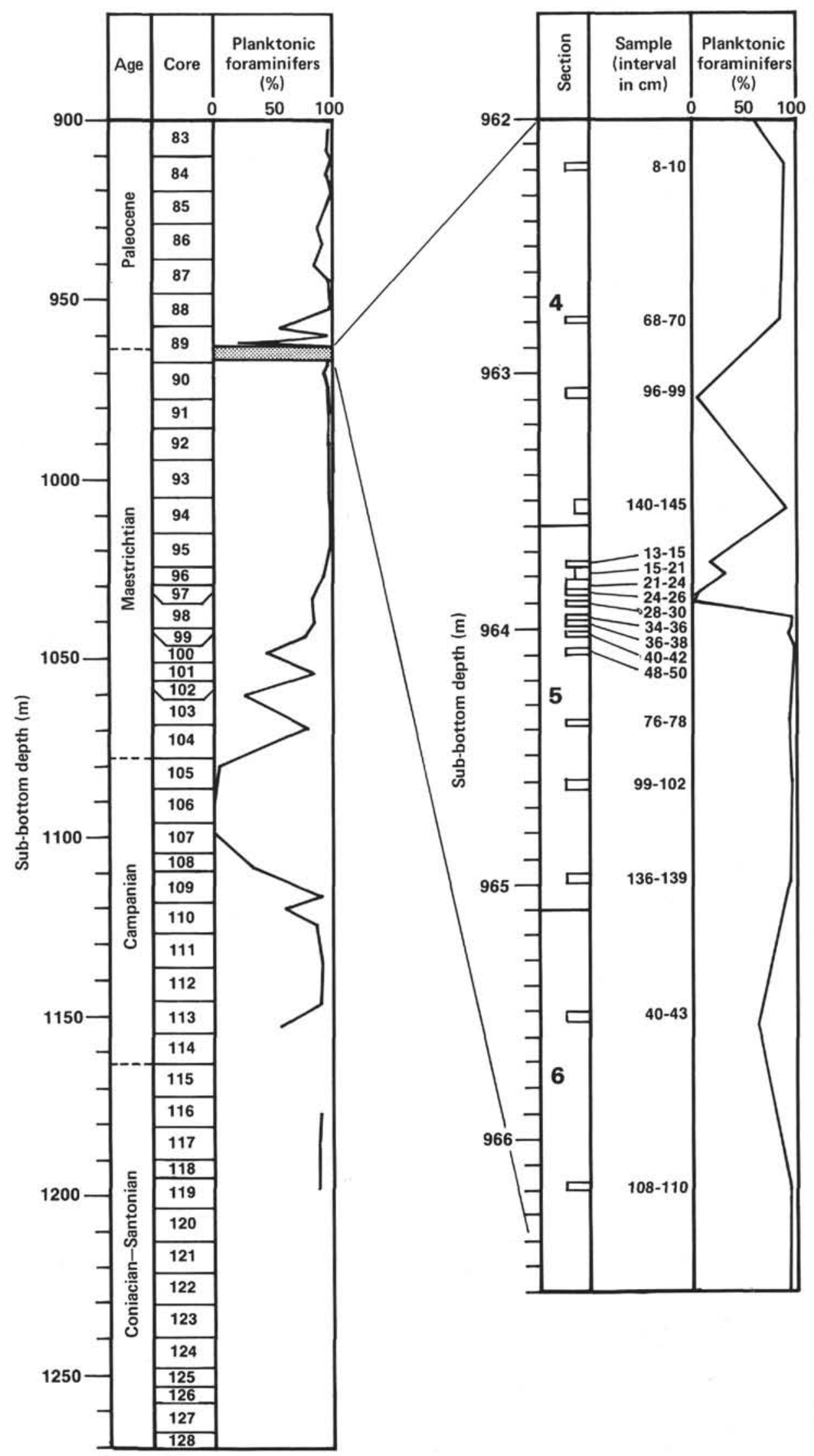

Figure 5. Planktonic foraminifers as a percent of the total foraminiferal fauna at Site 516. Coiumn on right shows an expanded view of the planktonic foraminiferal abundance across the Cretaceous/Tertiary boundary. 
The $28-30 \mathrm{~cm}$ horizon is characterized by an absence of bioturbation and by a foraminiferal assemblage (both autochthonous and displaced individuals) showing strong differential solution, which suggests a short episode of oxygen-minimum conditions or possibly close proximity to such a layer.

Boundary events occurring in the interval are: the first increase of iridium above background count at 34.5$36.5 \mathrm{~cm}$, an iridium peak at $33.0-33.5 \mathrm{~cm}$, the first occurrence of the Paleocene nannofossil indicator Biantholithus sparsus at $33.5 \mathrm{~cm}$, and the probable base of the Paleogene planktonic foraminiferal Zone P1a at 29 $\mathrm{cm}$. For the following discussion, the Cretaceous/Tertiary boundary is arbitrarily placed in the unsampled interval between 30 and $34 \mathrm{~cm}$.

A shift in benthic foraminiferal faunal character occurred during the latest Maestrichtian and earliest $\mathrm{Pa}$ leocene at Site 516. The change is substantial and almost exclusively at the species level. Compared to the planktonic groups that suffered abrupt mass extinction, the benthic foraminiferal turnover was comparatively moderate and occurred over a period of hundreds of thousands of years. Changes in the benthic fauna are evident through comparison of the number of local species extinctions and introduction of new species occurring in time intervals of $1 \mathrm{Ma}$ and $0.5 \mathrm{Ma}$. Data pertaining to these faunal changes are summarized in Figure 6.

Most striking is the accelerated rate of last occurrences in the final $2 \mathrm{Ma}$ of the Maestrichtian, when the incidence of disappearance increases $200 \%$ in each of the 66-67 Ma and 65-66 Ma intervals. A climax in extinctions is reached in the final $0.5 \mathrm{Ma}$. Partial compensation occurs in the last $1 \mathrm{Ma}$ of the Maestrichtian with a four-fold increase in first appearances. On balance, however, it is a time of decreasing diversity. Thirty-three percent of the species present in the final $1 \mathrm{Ma}$ and $28 \%$ of the species present in Site 516 in the final $0.5 \mathrm{Ma}$ do not survive to the end of the Cretaceous. These include a few species (Allomorphina trochoides, Ellipsoglandulina exponens, and Osangularia lens) whose ranges extend well into the Paleocene in Trinidad and/or western Europe. Rapid replacement continues during the earliest 1 m.y. of the Paleocene, but the number of extinctions decline $63 \%$ to a total of 10 . Again, most change occurs in the $0.5 \mathrm{Ma}$, after the end of the Cretaceous. A low rate of turnover is reestablished by about $63 \mathrm{Ma}$. The extinction rate may be estimated higher in the uppermost Maestrichtian and lower in lowest Paleocene if some apparent Cretaceous survivors above the boundary are actually interpreted as reworked individuals.

Benthic faunal change across the Cretaceous/Tertiary boundary in Hole $516 \mathrm{~F}$ appears independent of the planktonic groups, although the peak of change more or less coincides with the planktonic mass extinction event. The substantial and progressive change in the benthics reflects important alteration of environmental conditions in the deep sea that developed during the closing phase of the Cretaceous. The nature of the change is not apparent from the benthic foraminifers nor from their enclosing sediments.

\section{COMPARISON OF UPPER CRETACEOUS- PALEOCENE BENTHIC FORAMINIFERAL FAUNAS AT SITES 357 AND 516}

In spite of the close proximity and great similarity of sediments in Sites 357 and 516, there are some differences. Sediments at both sites consist primarily of bioturbated nannofossil limestone; Site 357, however, shows much evidence of gravity-flow deposits, minor conglomerate, glauconite layers, and common transported foraminifers (Sliter, 1977b), and these sedimentary features are little developed at Site 516.

The thickness of Cretaceous sediments is comparable at both sites, but Paleocene strata at Site 357, are considerably thinner (i.e., $40 \mathrm{~m}$ versus $65 \mathrm{~m}$ at Site 516) because of two hiatuses. A short interval in the lower Paleocene equivalent to the planktonic Zone $\mathrm{P} 1 \mathrm{~b}$ and a much longer one in the upper Paleocene corresponding to planktonic Zones P5 and P6a (Boersma, 1977) are both missing. Both sites show a similar accumulation rate and a similar subsidence history of deepening from shallow bathyal depths in Coniacian-Santonian to lower bathyal depths in the Paleocene. Interpreted depths of deposition based on sub-bottom depths and foraminiferal assemblages indicate Site 357 was deeper than Site 516 , possibly by as much as $300 \mathrm{~m}$.

Cretaceous assemblages at both sites show similar preservation but those at Site 357 exhibit greater diversity. On the whole, the Cretaceous benthic fauna at both sites compare closely; there are only minor differences. Most notable are the agglutinated and nodosariid taxa that are common at Site 357 but are more limited in occurrence at Site 516.

Site 357 Paleocene assemblages from the collection of R. C. Tjalsma examined during this study consist of abundant individual specimens and show only nominal differences with coeval assemblages at Site 516. The degree of preservation is much higher at Site 357; this difference is probably caused by the preferential preservation at Site 516. The paucity of individual specimens previously attributed to the Site 357 Paleocene fauna (Boersma, 1977; Perch-Nielson, Supko et al., 1977) is not substantiated by our observations.

A dissolution episode characterized by some decrease in benthic diversity, and by the absence of the planktonic element observed in upper Campanian strata at Sites 356 and 357, is also developed in coexistent strata (Cores $516 \mathrm{~F}-105$ to $516 \mathrm{~F}-108)$ at Site 516.

\section{FAUNAL REFERENCE LIST ${ }^{2}$}

Alabamina creta (Finlay) $=$ Pulvinulinella creta Finlay, 1940, R. Soc . N.Z. Trans. Proc., 69:643, pl. 66, figs. 187-192.

Allomorphina cretacea Reuss, 1851, Haidinger's Naturwiss. Abh., $4: 42$, pl. 5 , fig. 6.

Allomorphina minuta Cushman, 1936, Contrib. Cushman Lab. Foraminiferal Res., 12:72, pl. 13, fig. 3.

\footnotetext{
2 In accordance with common practice, most of the references pertaining to these species are listed only here. For references cited in the text, please see the reference list at the end of the chapter.
} 


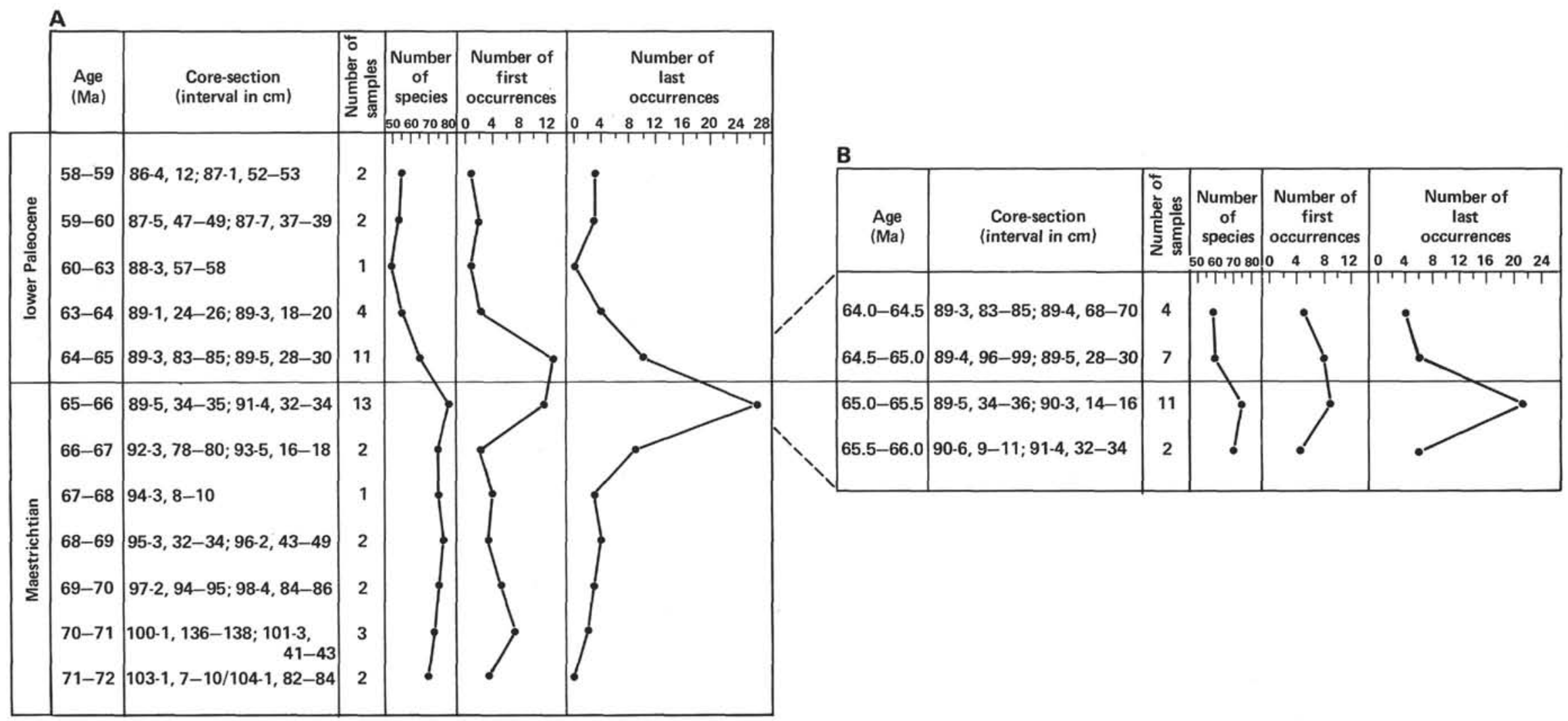

Figure 6. Maestrichtian-lower Paleocene benthic foraminiferal data at Hole 516F. Data are arranged in $1 \mathrm{Ma}$ intervals (except for $60-63 \mathrm{Ma}$ interval) in A and 0.5 Ma intervals in B. Age is based on magnetic polarity Events 25 to 33 and corresponds to the LaBrecque et al. (1977) magnetic reversal time scale. Species occurring only once have been omitted. 
Allomorphina trochoides (Reuss) $=$ Globigerina trochoides Reuss, 1845, Die Versteinerungen der Böhmischen Kreideformation (Pt. 1): Stuttgart (E. Schweizerbart), p. 36, pl. 12, fig. 22.

Ammodiscus cretaceus (Reuss) = Operculina cretacea Reuss, 1845, Die Versteinerungen der Böhmischen Kreideformation (Pt. 1): Stuttgart (E. Schweizerbart) p. 35, pl. 13, figs. 64-65.

Anomalinoides welleri (Plummer) $=$ Truncatulina welleri Plummer, 1927, Univ. Tex. Bull., 2644:143, pl. 9, fig. 9.

Aragonia semireticulata (LeRoy) $=$ Bolivina semireticulata LeRoy, 1953, Geol. Soc. Amer., Mem., 24:20, pl. 8, fig. 26.

Aragonia velascoensis $($ Cushman $)=$ Textularia velascoensis Cushman, 1925, Contrib. Cushman Lab. Foraminiferal Res., 1:18, pl. 3, fig. 1. Some specimens at hand are distinguished by great thickness in transverse section, a characteristic of $A$. ouezzanensis, but otherwise are identical with Cushman's description and figure.

Astacolus crepidulus White, 1928, J. Paleontol., 2:202, pl. 28, fig. 11.

Astacolus gibbus (d'Orbigny) = Cristellaria gibba d'Orbigny, 1839. Foraminifères. In de la Sagra, Ramon, Histoire Physique, Politique, et Naturelle de l'ile Cuba: Paris (A. Bertrand), p. 40, pl. 7, figs. 20-21.

Astacolus jarvisi (Cushman) = Marginulina jarvisi Cushman, 1938, Contrib. Cushman Lab. Foraminiferal Res., 14:35, pl. 5, figs. 17-18.

Astacolus richteri $($ Brotzen) = Planularia richteri Brotzen, 1936, Arsb . Sver. Geol. Unders. Ser. C, No. 396, Vol. 30(3), p. 59, pl. 3, fig. 3.

Bandyella beckmanni Proto Decima and Bolli, 1978, Init. Rpts. DSDP, 40 p. 790 , pl. 3, fig. 12.

Bandyella greatvalleyensis $($ Trujillo) $=$ Pleurostomella greatvalleyen sis Trujillo, 1960, J. Paleontol., 34:345 pl. 50, figs. 5-6.

Bathysiphon sp. The present specimens are fragmented and flattened small smoothly finished tubes.

Bolivinoides delicatulus Cushman $=B$. decorata (Jones) var. delicatula Cushman, 1927, Contrib. Cushman Lab. Foraminiferal Res., $2: 90$, pl. 12 , fig. 8 .

Bolivinoides draco draco (Marsson), Hilterman and Koch, 1950, Geol. Jahrb., 64 (1943-1948):598; fig. 1, no. 72-73; figs. 2-4, no. 52-54, 58-60; fig. 5, no. 53, 69-70.

Bolivinoides draco miliaris Hilterman and Koch, 1950, Geol. Jahrb. 64 (1943-1948):604; figs. 2-4, no. 26, 32-34, 39-41, 46-48; fig. 5, no. 39 .

Bolivinoides granulatus Hofker, 1957, Geol. Jahrb. Beih., 27:250 textfigs. 303d-f, 307a-h, 310a-f.

Bolivinoides strigillatus $($ Chapman $)=$ Bolivina strigillata Chapman, 1892, Geol. Soc. London Q.J., 48:515, pl. 15, fig. 10.

Bulimina midwayensis Cushman and Parker $=B$. arkadelphiana Cushman and Parker var. midwayensis Cushman and Parker, 1936, Contrib. Cushman Lab. Foraminiferal Res., 12:42, pl. 7, figs. 9-10.

Bulimina trinitatensis Cushman and Jarvis, 1928, Contrib. Cushman Lab. Foraminiferal Res., 4:102, pl. 14, fig. 12.

Bulimina tuxpamensis Cole, 1928, Am. Paleontol. Bull., 14:212, pl. 32, fig. 23.

Bulimina velascoensis $($ Cushman $)=$ Gaudryina velascoensis Cushman, 1925, Contrib. Cushman Lab. Foraminiferal Res., 1:20, pl. 3, fig. 7.

Buliminella beaumonti Cushman and Renz, 1946, Cushman Lab. Foraminiferal Res. Spec. Publ., 18:36, pl. 6, fig. 7.

Ceratobulimina perplexa Plummer) $=$ Rotalia perplexa Plummer, 1927, Univ. Tex. Bull., 2644:156, pl. 12, fig. 2.

Cibicides excavatus Brotzen, 1936, Arsb. Sver. Geol. Unders., Ser. C, No. 396, Vol. 30(3), p. 189, pl. 13, figs. 7-8.

Cibicidoides dayi (White)=Planulina dayi White, 1928, J. Paleontol., 2:300, pl. 41, fig. 3 .

Cibicidoides pseudoperlucidus $($ Bykova $)=$ Cibicides $($ Gemellides $)$ pseudoperlucidus Bykova, 1954, Vses. Neft. Nauchno-Issled. Geologo, razved. Inst. Tr. (VNIGRI), N.S., 80:190, pl. 34, fig. 1.

Coryphostoma incrassata (Reuss) = Bolivina incrassata Reuss, 1851, Haidinger's Naturwiss. Abh., 4:29, pl. 5, fig. 13.

Coryphostoma limonense (Cushman) = Bolivina incrassata var. limonensis Cushman, 1926, Contrib. Cushman Lab. Foraminiferal Res., 2:19, pl. 2, fig. 2.

Dentalina alternata $($ Jones) $=$ Nodosaria zippei Reuss var. alternata Jones, 1886, Belfast Nat. Field Club Proc., N. Ser. 1 (1884-1885), Appendix 9 (1886):330, pl. 27, fig. 10.
Dentalina basiplanata Cushman, 1938, Contrib. Cushman Lab. Foraminiferal Res., 14:38, pl. 6, figs. 6-8.

Dentalina catenula Reuss, 1860, K. Akad. Wiss. Wien Math.-Naturwiss. Kl. Sitzungsber., 40:185, pl. 3, fig. 6.

Dentalina gracilis d'Orbigny 1840, Soc. Geol. Fr. Mem., Ser. 1, 4:14, pl. 1, fig. 5 .

Dentalina legumen Reuss, 1851, Haidinger's Naturwiss. Abh., 4:10, pl. 1, fig. 14.

Dentalina spp. This category includes sparse numbers of unidentifiable individuals in our Paleocene samples assignable to Dentalina.

Dorothia beloides von Hillebrandt, 1962, Bayer. Akad. Wiss. Math.Naturwiss. Kl. Abh., N. S., 108:39, pl. 2, figs. 8-14; pl. 15, figs. 12-13.

Dorothia bulletta (Carsey) = Gaudryina bulletta Carsey, 1926, Univ . Tex. Bull., 2612:28, pl. 4, fig. 4.

Dorothia cubensis $($ Cushman and Bermudez) $=$ Tritaxilina cubensis Cushman and Bermudez, 1937, Contrib. Cushman Lab. Foraminiferal Res., 13:7.

Dorothia oxycona (Reuss) $=$ Gaudryina oxycona Reuss, $1860, K$. Akad. Wiss. Wien Math.-Naturwiss. Kl. Sitzungsber., 40:229, pl. 12, fig. 3 .

Dorothia pupa (Reuss) $=$ Textularia pupa Reuss, 1860, K. Akad. Wiss. Wien Math.-Naturwiss. Kl. Sitzungsber., 40:232, pl. 13, fig. 4.

Dorothia retusa $($ Cushman $)=$ Gaudryina retusa Cushman, 1926, Am . Assoc. Pet. Geol. Bull., 10:588, pl. 16, fig. 10.

Ellipsoglandulina exponens (Brady) $=$ Ellipsodina exponens $\mathrm{Brady}$, 1892, In Jukes-Brown and Harrison, Q.J. Geol. Soc. London, 48: 198.

Ellipsoidella robusta $($ Cushman $)=$ Nodosarella robusta Cushman, 1943, Contrib. Cushman Lab. Foraminiferal Res., 19:92, pl. 16, fig. 8 .

Ellipsopolymorphina velascoensis $($ Cushman $)=$ Ellipsoglandulina velascoensis Cushman, 1926, Am. Assoc. Pet. Geol., Bull., 10:590, pl. 16, fig. 7.

Eouvigerina americana Cushman, 1926, Contrib. Cushman Lab. Foraminiferal Res., 2(1):4, pl. 1, fig. 1.

Eouvigerina excavata Cushman, 1940, Contrib. Cushman Lab. Foraminiferal Res., 16:66, pl. 11, fig. 18.

Fissurina alata Reuss, 1851. Z. Dtsch. Geol. Ges., 3:58 pl. 3, fig. 1.

Fissurina oblonga Reuss, 1863, K. Akad. Wiss. Wien Math-Naturwiss. Kl. Sitzungsber., 46:339, pl. 7, fig. 89.

Fissurina orbignyana Sequenza, 1862, fide Ellis, B. F., and Messina, A. R., 1940, Catalogue of Foraminifera: New York (Mus. Nat. Hist. Spec. Publ.).

Frondicularia jarvisi Cushman, 1939, Contrib. Cushman Lab. Foraminiferal Res., 15:91, pl. 16, fig. 6.

Gaudryina aissana Ten Dam and Sigal, 1950, Contrib. Cushman Found. Foraminiferal Res., 1:31, pl. 2, fig. 2.

Gaudryina laevigata Franke, 1914, Z. Dtsch. Geol. Ges., 66:431, pl. 27, figs. 1-2.

Gaudryina pyramidata Cushman $=G$. laevigata Franke var. pyramidata Cushman, 1926, Am. Assoc. Pet. Geol. Bull., 10:587, pl. 16, fig. 8 .

Gavelinella beccariiformis (White) $=$ Rotalia beccariiformis White, 1928, J. Paleontol., 2(4):287, pl. 39, fig. 32.

Gavelinella costata Brotzen of Hofker, 1957, Geol. Jahrb. Beih., 27: 288, text-fig. 341.

Gavelinella danica $($ Brotzen $)=$ Cibicides danica Brotzen, 1940, Arsb . Sver. geol. Unders. Ser. C, No. 435, Vol. 34(5), p. 31, text-fig. 7:2. Specimens from Maestrichtian samples differ from Brotzen's description in their smaller size, more narrow cross-sectional width, and more gradually increasing size of ultimate whorl chambers.

Gavelinella eriksdalensis $($ Brotzen) $=$ Cibicides (Cibicidoides) eriks dalensis Brotzen, 1936, Arsb. Sver. Geol. Unders., Ser. C, No. 396, Vol. 30(3), p. 193, fig. 69 , pl. 14, fig. 5.

Gavelinella hyphalus (Fisher) = Anomalinoides hyphalus Fisher, 1969, Palaeontology, 12:197, text-fig. 3. A broad species concept has been applied here in which are included lowest Paleocene and upper Maestrichtian specimens differing from typical $G$. hyphalus in their more sharply rounded periphery and evolute dorsal side.

Gavelinella monterelensis $($ Marie) = Anomalina monterelensis Marie, 1941, Mus. Nat. Hist. Nat. Mem., N.S., 12:243, pl. 37, fig. 342.

Gavelinella nacatochensis $($ Cushman $)=$ Planulina nacatochensis Cushman, 1938, Contrib. Cushman Lab. Foraminiferal Res., 14:50, pl. 8 , fig. 9 . 
Gavelinella stephensoni $($ Cushman $)=$ Cibicides stephensoni Cushman, 1938, Contrib. Cushman Lab. Foraminiferal Res., 14:70, pl. 12, fig. 5 .

Gavelinella velascoensis (Cushman) $=$ Anomalina velascoensis Cushman, 1925, Contrib. Cushman Lab. Foraminiferal Res., 1:21, pl. 3, fig. 3 .

Gavelinella sp. A number of specimens recovered from lower Paleocene samples are characterized by their circular outline, subacute periphery, planoconvex to biconvex tranverse section, numerous longer than high chambers that increase very gradually as added, and faintly curved sutures. In addition, most individuals develop a calcite plug on the umbilical side. It is possibly close to Neorotalia sp. of Said and Kenawy (1956, p. 153, pl. 6, fig. 13).

Globorotalites conicus (Carsey) $=$ Truncatulina refulgens Montfort var. conica Carsey, 1926, Univ. Tex. Bull., 2612:46, pl. 4, fig. 15.

Globorotalites multiseptus (Brotzen $=$ Globorotalia multisepta Brotzen 1936, Arsb. Sver. Geol. Unders., Ser. C, No. 396, Vol. 30(3), p. 161 , pl. 11, figs. 6-7.

Globulina lacrima (Reuss) = Polymorphina (Globulina) lacrima Reuss, 1845, Die Versteinerungen der Böhmischen Kreideformation (Pt. 1): Stuttgart (E. Schweizerbart), p. 40, pl. 12, fig. 6, pl. 13, fig. 83.

Globulina subsphaerica (Berthelin) = Polymorphina subsphaerica Berthelin, 1880, Soc. Geol. Fr. Mem., Ser. 3, 1(No. 5):58, pl. 4, fig. 18.

Glomospira corona Cushman and Jarvis = Glomospira charoides (Jones and Parker) var. corona Cushman and Jarvis, 1928, Contrib. Cushman Lab. Foraminiferal Res., 4:89, pl 12, figs. 9-11.

Glomospira gordialis (Jones and Parker) $=$ Trochammina squamata Jones and Parker, var. gordialis Jones and Parker, 1860, Q.J. Geol. Soc. London, 16:304.

Guttulina caudata d'Orbigny, 1826, Ann. Sci. Nat. Hist. Paris, Ser. 1, 7:266, no. 16; Fornasini, 1900, Bol. Soc. Geol. Ital., 19:137, textfig. 2 .

Guttulina communis d'Orbigny 1826, Ann. Sci. Nat. Paris, Ser. 1, 7: $266 \mathrm{pl}$. 12, figs. 1-4.

Gyroidinoides beisseli (White) = Gyroidina beisseli White, 1928, J. Paleontol., 2:291, pl. 39, fig. 7.

Gyroidinoides depressus (Alth) $=$ Rotalina depressa Alth, 1850, Haidinger's Naturwiss. Abh., 3:266, pl. 13, fig. 21.

Gyroidinoides girardanus (Reuss) = Rotalina girardana Reuss, 1851, Z. Dtsch. Geol. Ges., 3:73, pl. 5, fig. 34.

Gyroidinoides globosus (Hagenow) = Nonionina globosa Hagenow, 1842, Neues Jahrb. Min. Geogr. Geol. Petref., p. 574.

Gyroidinoides goudkoffi (Trujillo) $=$ Eponides goudkoffi Trujillo, 1960, J. Paleontol., 34:333, pl. 48, fig. 6.

Gyroidinoides nitidus (Reuss) = Rotalina nitida Reuss, 1845, Die Versteinerungen der Bohmischen Kreideformation (Pt. 1): Stuttgart, (E. Schweizerbart), p. 35, pl. 8, fig. 52, pl. 12, figs. 8, 20.

Gyroidinoides octocameratus (Cushman and Hanna) $=$ Gyroidina sol danii d'Orbigny subspecies octocamerata Cushman and Hanna, 1927, Calif. Acad. Sci. Proc. 4th Ser., 16:223, pl. 14, figs. 16-18.

Gyroidinoides praeglobosus (Brotzen) = Gyroidina praeglobosa Brotzen, 1936, Arsb. Sver. Geol. Unders. Ser. C, No. 396, Vol. 30(3), p. 159 , pl. 11, fig. 4.

Gyroidinoides quadratus (Cushman and Church) $=$ Gyroidina quad rata Cushman and Church, 1929, Calif. Acad. Sci. Proc., Ser. 4, 18:516, pl. 41, figs. 7-9. Rare individuals recovered from the Paleocene section differ from Cretaceous specimens in their lessoppressed and fewer whorls.

Lagena gracilis Williamson, 1848, Ann. Mag. Nat. Hist. Ser. 2, 1:13, pl. 1 , fig. 5 .

Lagena hispida Reuss, 1863, K. Akad. Wiss. Wien Math.-Naturwiss. Kl. Sitzungsber., 40:335, pl. 6, figs. 77-79.

Lagena sulcata $($ Walker and Jacob) $=$ Serpula $($ Lagena $)$ sulcata Walker and Jacob, 1798, In Kanmacher, F. Adams' Essays on the Microscope: London (Dillon and Keating), p. 634, pl. 14, fig. 5.

Lenticulina acuta (Reuss) $=$ Cristellaria acuta Reuss, $1860, K$. Akad . Wiss. Wien Math.-Naturwiss. Kl. Sitzungsb., 40:213, pl. 10, fig. 3.

Lenticulina macrodisca (Reuss) = Cristellaria macrodisca Reuss, 1862, K. Akad. Wiss. Wien Math.-Naturwiss. Kl. Sitzungsb., 46:78, pl. 9, fig. 5 .

Lenticulina midwayensis (Plummer) $=$ Robulus midwayensis Plummer, 1927, Univ. Tex. Bull., 2644:95, pl. 13, fig. 5.
Lenticulina muensteri $($ Roemer $)=$ Robulina münsteri Roemer, 1839, Die Versteinerungen des Norddeutschen Oolith-Gebirges, Ein Nachtrag: Hannover (Hahn'schen Hofbuchhandlung), p. 48, pl. 22, fig. 29.

Lenticulina velascoensis White, 1928, J. Paleontol., 2:199, pl. 28, fig. 8.

Lenticulina whitei Tjalsma and Lohmann n. sp., Micropaleontology Spec. Publ. 4 (in press). This species was originally reported from the Velasco Formation, eastern Mexico, as L. gaultina (Berthelin) by White (1928, p. 198, pl. 28, fig. 6).

Lenticulina spp. Few numbers of unidentifiable specimens occur in a minority of samples.

Lingulina pygmaea Reuss, 1875, Palaeontographica, Beitr. Naturgesch., Vol. 20, Pt. 2 (1872-1875), Sec. 4, p. 90, pl. 2 (20), fig. 23.

Loxostomum eleyi $($ Cushman $)=$ Bolivinita eleyi Cushman, 1927, Contrib. Cushman Lab. Foraminiferal Res., 2:91, pl. 12, fig. 11.

Marginulina armata Reuss, 1860, K. Akad. Wiss. Wien Math.-Naturwiss. Kl. Sitzungsber., 40:209, pl. 7, fig. 7.

Marginulina austiana Cushman, 1937, Contrib. Cushman Lab. Foraminiferal Res., 13:92, pl. 13, figs. 1-4.

Marginulina hamuloides Brotzen, 1936, Arsb. Sver. Geol. Unders. Ser. C, No. 396, p. 68, pl. 10, figs. 10-11.

Marginulina oligostegia Perner, 1892, Ceska Akad. Cis. Fr. Josefa, Prague: Paleontogr. Bohemiae, 2(2):61, pl. 5, figs. 11-12.

Marginulina siliqua Cushman, 1938, Contrib. Cushman Lab. Foraminiferal Res., 14: p. 35, pl. 5, figs. 15-16.

Marginulinopsis texasensis $($ Cushman $)=$ Marginulina texasensis Cushman, 1938, Contrib. Cushman Lab. Foraminiferal Res., 14:95.

Neoeponides hillebrandti Fisher, 1969, Palaeontology, 12:197. This species has been reported previously from eastern Mexico as Rotalia cf. partschiana (d'Orbigny) (White 1928, p. 288) and from Bavaria as Eponides whitei by Hillebrandt (1962, p. 106).

Neoeponides lunata $($ Brotzen $)=$ Eponides lunata Brotzen, 1948, Arsb. Sver. Geol. Unders., Ser. C, No. 493, Vol. 42(2), p. 77, pl. 10 , figs. $17-18$

Neoflabellina semireticulata $($ Cushman and Jarvis) $=$ Flabellina semireticulata Cushman and Jarvis, 1928, Contrib. Cushman Lab. Foraminiferal Res., 4(4):98, pl. 13, fig. 14.

Nodosaria velascoensis Cushman $=N$. fontannesi (Berthelin) var. ve lascoensis Cushman, 1926, Am. Assoc. Pet. Geol. Bull., 10:594, pl. 18 , fig. 12.

Nonion havanense Cushman and Bermudez, 1937, Contrib. Cushman Lab. Foraminiferal Res., 13:19, pl. 2, figs. 13-14.

Nonionella austinana Cushman, 1933, Contrib. Cushman Lab. Foraminiferal Res., 9:57, pl. 7, fig. 2 .

Nuttallides crassaformis (Cushman and Siegfus) $=$ Astigerina crassaformis Cushman and Siegfus, 1935, Contrib. Cushman Lab. Foraminiferal Res., 11:94, pl. 14, fig. 10.

Nuttallides truempyi $($ Nuttall $)=$ Eponides trümpyi Nuttall, 1930, J. Paleontol., 4:287, pl. 24, figs. 9, 13-14.

Nuttallinella florealis (White) $=$ Gyroidina florealis White, 1928, $J$. Paleontol., 2:293, pl. 40, fig. 3.

Nuttallinella sp. Fairly common at several lower Paleocene and uppermost Cretaceous horizons are rotaliform specimens, herein assigned to Nuttallinella, developing a strongly convex ventral side, flat to slightly convex dorsal side, two to two and one-half narrow whorls, and eight to nine chambers in the final whorl. $N$. sp. has affinities with the Marie species from the Late Cretaceous of the Paris Basin (described as Eponides monterelensis Marie, 1941) but is smaller and develops more chambers per whorl and a more or less smooth periphery.

Oolina apiculata Reuss, 1851, Haidinger's Naturwiss. Abh., 4:22, pl. 2, fig. 1 .

Oolina delicata Sliter, 1968, Univ. Kansas Paleontol. Contrib. Serial no. 49 (Art. 7):80 pl. 10, figs. 21-22.

Oolina morsei $($ Kline $)=$ Entosolenia morsei Kline, 1943, Miss. Geol. Surv. Bull., 53:48, pl. 4, fig. 17.

Oridorsalis biconvexus (Marie) = Eponides biconvexa Marie, 1941 , Mus. Nat. Hist. Nat. Mém. Paris, N. S., 12(1):224, pl. 34, fig. 324.

Oridorsalis umbonatus (Reuss) $=$ Rotalina umbonata Reuss, 1851, Z . Dtsch. Geol. Ges., 3:75, pl. 5, fig. 35.

Osangularia cordieriana (d'Orbigny) = Rotalina cordieriana d'Orbigny, 1840, Soc. Geol. Fr. Mem., 4(1):33, pl. 3, figs. 9-11. 
Osangularia lens Brotzen, 1940, Arsb. Sver. Geol. Unders., Ser. C, No. 435, Vol. 34(5), p. 30, text-fig. 8, 1.

Osangularia plummerae Brotzen, 1940, Arsb. Sver. Geol. Unders., Ser. C, No. 435 , Vol 34(5), p. 30.

Osangularia velascoensis (Cushman) $=$ Truncatulina velascoensis Cushman, 1925, Contrib. Cushman Lab. Foraminiferal Res., $1: 20$, pl. 3 , fig. 2 .

Planularia liebusi Brotzen, 1936, Arsb. Sver. Geol. Unders., Ser. C, No. 396 , Vol. $30(3)$, p. 60 , pl. 4 , figs. 5-6.

Pleurostomella austinana Cushman, 1933, Contrib. Cushman Lab. Foraminiferal Res., 9:64, pl. 7, fig. 13.

Pleurostomella subnodosa Reuss, 1860, K. Akad. Wiss. Wien Math.Naturwiss. Kl. Sitzungsber., 40:204, pl. 8, fig. 2.

Pleurostomella torta Cushman, 1926, Contrib. Cushman Lab. Foraminiferal Res., $2: 18$, pl. 2, fig. 7 .

Praebulimina carseyae $($ Plummer) = Buliminella carseyae Plummer, 1931, Univ. Tex. Bull., 3101:179, pl. 8, fig. 9.

Praebulimina cushmani (Sandidge) $=$ Buliminella cushmani Sandidge, 1932, J. Paleontol., 6:280, pl. 42, figs. 18-19.

Praebulimina reussi $($ Morrow) $=$ Bulimina reussi Morrow, 1934, J Paleontol., 8:195, pl. 29, fig. 12.

Praebulimina triangularis (Cushman and Parker) $=$ Bulimina triangularis Cushman and Parker, 1935, Contrib. Cushman Lab. Foraminiferal Res., 11:97, pl. 15, fig. 4.

Pseudonodosaria bistegia $($ Olszewski) $=$ Cristellaria bistegia Olszewski, 1875, Spraw. Kom. Fiz. Akad. Umiej. Krakowie, 9:115, pl. 1, fig. 9.

Pseudonodosaria manifesta (Reuss) = Glandulina manifesta Reuss, 1851, Haidinger's Naturwiss. Abh., 4:22, pl. 1, fig. 4.

Pseudouvigerina plummerae Cushman, 1927, Contrib. Cushman Lab. Foraminiferal Res., 3:115, pl. 23, fig. 8 .

Pullenia coryelli White, 1929, J. Paleontol., 3:56, pl. 5, fig. 22.

Pullenia cretacea Cushman, 1936, Contrib. Cushman Lab. Foraminiferal Res., 12:75, pl. 13, fig. 8 .

Pullenia jarvisi Cushman, 1936, Contrib. Cushman Lab. Foraminiferal Res., 12:77, pl. 13, fig. 6.

Pullenia minuta Cushman, 1936, Contrib. Cushman Lab. Foraminiferal Res., 12:77, pl. 13, fig. 7.

Pyramidina rudita (Cushman and Parker) = Bulimina rudita Cushman and Parker, 1936, Contrib. Cushman Lab. Foraminiferal Res., 12:45.

Quadrimorphina allomorphinoides (Reuss) = Valvulina allomorphinoides Reuss, 1860, K. Akad. Wiss. Wien Math.-Naturwiss. Kl. Sitzungsber., 40:223, pl. 11, fig. 6 .

Reophax trinitatensis $($ Cushman and Renz) $=$ Hormosina globulifera Brady var. trinitatensis Cushman and Renz, 1946, Cushman Lab. Foraminiferal Res. Spec. Publ., 18:14, pl. 1, figs. 15-19.

Reussella szajnochae (Grzybowski) = Verneuilina szajnochae Grzybowski, 1896, Akad. Umiej. Krakowie Wydz. Mat.-Przyr., Rozpr., Ser. 2, 10:287, pl. 9, fig. 19.

Rhabdammina discreta Brady, 1881, Q.J. Microsc. Sci., N. S., 21:48.

Saracenaria navicula (d'Orbigny) = Cristellaria navicula d'Orbigny, 1840, Soc. Geol. Fr. Mem., 4:27, pl. 2, figs. 19-20.

Saracenaria triangularis (d'Orbigny) = Cristellaria triangularis d'Orbigny, 1840, Soc. Geol. Fr. Mem., 4(1):27, pl. 2, figs. 21-22.

Spiroplectammina dentata $($ Alth) $=$ Textularia dentata Alth, 1850, Haidinger's Naturwiss. Abh., 3:262, pl. 13, fig. 13.

Spiroplectammina praelonga (Reuss) = Textularia praelonga Reuss, 1845, Die Versteinerungen der Bohmischen Kreideformation (Pt. 1): Stuttgart (E. Schweizerbart), p. 39, pl. 12, fig. 14.

Spiroplectammina sigmoidina Lalicker, 1935, Contrib. Cushman Lab. Foraminiferal Res., 11:7, pl. 1, figs. 10-11.

Spiroplectammina spectabilis (Grzybowski) $=$ Spiroplecta spectabilis Grzybowski, 1896 Akad. Umiej. Krakowie Wydz. Mat.-Przyr. Rozpr., Ser. 2, 10:293, pl. 12, fig. 12.

Spiroplectammina subhaeringensis (Grzybowski) = Textularia subhaeringensis Grzybowski, 1896 Akad. Umiej. Krakowie Wydz. Mat.-Przyr. Rozpr., Ser. 2, 10:285, pl. 9, figs. 13, 16.

Stensioeina pommerana Brotzen, 1936, Arsb. Sver. Geol. Unders., Ser. C, No. 396, Vol. 30(3), p. 166.

Stilostomella plummerae $($ Cushman $)=$ Ellipsonodosaria plummerae Cushman, 1940, Contrib. Cushman Lab. Foraminiferal Res., 16 (1):69, pl. 12, figs. 4-5.
Stilostomella pseudoscripta $($ Cushman $)=$ Ellipsonodosaria pseudoscripta Cushman, 1937, Contrib. Cushman Lab. Foraminiferal Res., 13:103, pl. 15, fig. 14.

Tritaxia amorpha $($ Cushman $)=$ Clavulina amorpha Cushman, 1926, Am. Assoc. Pet. Geol. Bull., 10:589 pl. 17, fig. 5.

Tritaxia aspera $($ Cushman $)=$ Clavulina trilatera Cushman var. aspera Cushman 1926, Am. Assoc. Pet. Geol., Bull., 10:589, pl. 17, fig. 3 .

Tritaxia globulifera $($ ten Dam and Sigal $)=$ Pseudoclavulina globulif era ten Dam and Sigal, 1950, Contrib. Cushman Found. Foraminiferal Res., 1:32, pl. 2, figs. 5-7.

Tritaxia trilatera $($ Cushman $)=$ Clavulina trilatera Cushman, 1926, Am. Assoc. Pet. Geol., Bull., 10:588, pl. 17, fig. 2.

Trochammina boehmi Franke, 1928, Abh. Preuss. Geol. Landesanst., N. S., 111:174, pl. 15, fig. 24.

Vaginulina trilobata (d'Orbigny) = Marginulina trilobata d'Orbigny, 1840, Soc. Geol. Fr. Mem., 4:16, pl. 1, figs. 16-17.

Valvulineria lenticula (Reuss) $=$ Rotalina lenticula Reuss, 1845, Die Versteinerungen der Böhmischen Kreideformation (Pt. 1): Stuttgart (E. Schweizerbart), p. 35, pl. 12, figs. 17a-c.

\section{ACKNOWLEDGMENTS}

I thank Drs. P. F. Barker, R. L. Carlson, and D. A. Johnson, cochief scientists for Leg 72, for making this material available for study. I am indebted to Dr. R. C. Tjalsma (shipboard scientist on Leg 72) for suggesting the study, giving freely of his time, and providing encouragement, invaluable information, and constructive criticism during the project. Thanks are due to Dr. R. Lighty who examined several carbonate thin sections, J. Etter and Dr. W. Sliter who reviewed the manuscript, B. Tuttle who prepared the samples, A. White who provided the scanning electron micrographs (on a JEOL JSM$35 \mathrm{C}$ SEM), and $\mathrm{S}$. Hanna who typed the manuscript. This study was done under the auspices of Cities Service Research, at their Technology Center, Tulsa, Oklahoma.

\section{REFERENCES}

Beckmann, J. P., 1960. Distribution of benthonic foraminifera at the Cretaceous-Tertiary boundary of Trinidad (West Indies). Rept. Intern. Geol. Congr., 21(pt. 5):57-69.

1972. The foraminifera and some associated microfossils of Sites 135 to 144. In Hayes, D. E., Pimm, A. C., et al., Init. Repts. DSDP, 14: Washington (U.S. Govt. Printing Office), 389-420.

1978. Late Cretaceous smaller benthic foraminifers from Sites 363 and 364 DSDP Leg 40, southeast Atlantic Ocean. In Bolli, H. M., Ryan, W. B. F., et al., Init. Repts. DSDP, 40: Washington (U.S. Govt. Printing Office), 759-781.

Boersma, A., 1977. Cenozoic planktonic foraminifera-DSDP Leg 39 (South Atlantic). In Supko, P. R., Perch-Nielsen, K., et al., Init. Repts. DSDP, 39: Washington (U.S. Govt. Printing Office), 567-587.

Douglas, R. G., 1973. Benthonic foraminiferal biostratigraphy in the central North Pacific, Leg 17, Deep Sea Drilling Project. In Winterer, E. L., Ewing, J. I., et al., Init. Repts. DSDP, 17: Washington (U.S. Govt. Printing Office), 607-672.

Hillebrandt, A. von, 1962. Das Paleozan und seine foraminiferenfauna in becken von Reichenhall und Salzburg. Bayer. Akad. Wiss. Math-Naturwiss. Kl. Abh., n.f., 108:1-182.

LaBrecque, J. L., Kent, D. V., and Cande, S. C., 1977. Revised magnetic polarity time scale for Late Cretaceous and Cenozoic time. Geology, 5:330-335.

Marie, P., 1941. Les foraminiferes de la Craie: Les foraminiferes de la Craie a Belemnitella mucronata du bassin de Paris. Mem. Mus. Nat. Hist. Nat. N. Ser., 12:1-296.

Maxwell, A. E., Von Herzen, R. P., and Shipboard Scientific Party, 1970a. Site 21. In Maxwell, A. E., Von Herzen, R. P., et al., Init. Repts. DSDP, 3: Washington (U.S. Govt. Printing Office), 367-411.

1970b. Site 22. In Maxwell, A. E., Von Herzen, R. P., et al., Init. Repts. DSDP, 3: Washington (U.S. Govt. Printing Office), 413-439.

Perch-Nielsen, K., Supko, P. R., and Shipboard Scientific Party, 1977. Site 357: Rio Grande Rise. In Supko, P. R., Perch-Nielsen, 
K., et al., Init. Repts. DSDP, 39: Washington (U.S. Govt. Printing Office), 231-327.

Proto Decima, F., and Bolli, H. M., 1978. Southeast Atlantic DSDP Leg 40, Paleogene benthic foraminifers. In Bolli, H. M., Ryan, W. B. F., et al., Init. Repts. DSDP, 40: Washington (U.S. Govt. Printing Office), 783-809.

Said, R., and Kenawy, A., 1956. Upper Cretaceous and lower Tertiary foraminifera from northern Sinai, Egypt. Micropaleontology, 2: $105-173$.

Sliter, W. V., 1968. Upper Cretaceous foraminifera from Southern California and Northwesern Baja California, Mexico. Kans. Univ. Paleontol. Contrib., Serial no, 49 (Art. 7).

1977a. Cretaceous foraminifers from the southwestern Atlantic Ocean, Leg 36, Deep Sea Drilling Project. In Barker, P., Dalziel, I. W. D., et al., Init. Repts. DSDP, 36: Washington (U.S. Govt. Printing Office), 519-573.

1977b. Cretaceous benthic foraminifers from the western South Atlantic Leg 39, Deep Sea Drilling Project. In Supko, P. R., Perch-Nielsen, K., et al., Init. Repts. DSDP, 39: Washington (U.S. Govt. Printing Office), 657-697.

Sliter, W. V., and Baker, R. A., 1972. Cretaceous bathymetric distribution of benthic foraminifers. J. Foraminiferal Res., 2:167-183.
Streeter, S. S., 1973. Bottom Water and benthonic foraminifera in the North Atlantic-Glacial-interglacial contrasts. Quat. Res., 3: 131-141.

Thierstein, H. R., 1981. Late Cretaceous nannoplankton and the change at the Cretaceous-Tertiary boundary. In Warme, J. E., Douglas, R. G., and Winterer, E. L. (Eds.), The Deep Sea Drilling Project: A Decade of Progress. Soc. Econ. Paleontol. Mineral., Spec. Publ., 32:355-394.

Tjalsma, R. C. 1977. Cenozoic foraminifera from the South Atlantic, DSDP Leg 36. In Barker, P., Dalziel, I. W. D., et al., Init. Repts. DSDP, 36: Washington (U.S. Govt. Printing Office), 493-517.

Tjalsma, R. C., and Lohmann, G. P., in press. Paleocene-Eocene bathyal and abyssal benthic foraminifera from the Atlantic Ocean. Micropaleontology Spec. Publ., 4.

Webb, P. N., 1973. Upper Cretaceous-Paleocene foraminifera from Site 208 (Lord Howe Rise, Tasman Sea), DSDP, Leg 21. In Burns, R. E., Andrews, J. E., et al., Init. Repts. DSDP, 21: Washington (U.S. Govt. Printing Office), 541-571.

White, M. P., 1928. Some index foraminifera of the Tampico embayment area of Mexico. J. Paleontol., 1:177-215.

Date of Initial Receipt: April 5, 1982 
APPENDIX

Distribution of Upper Cretaceous and Paleocene Benthic Foraminifers at Hole 516F

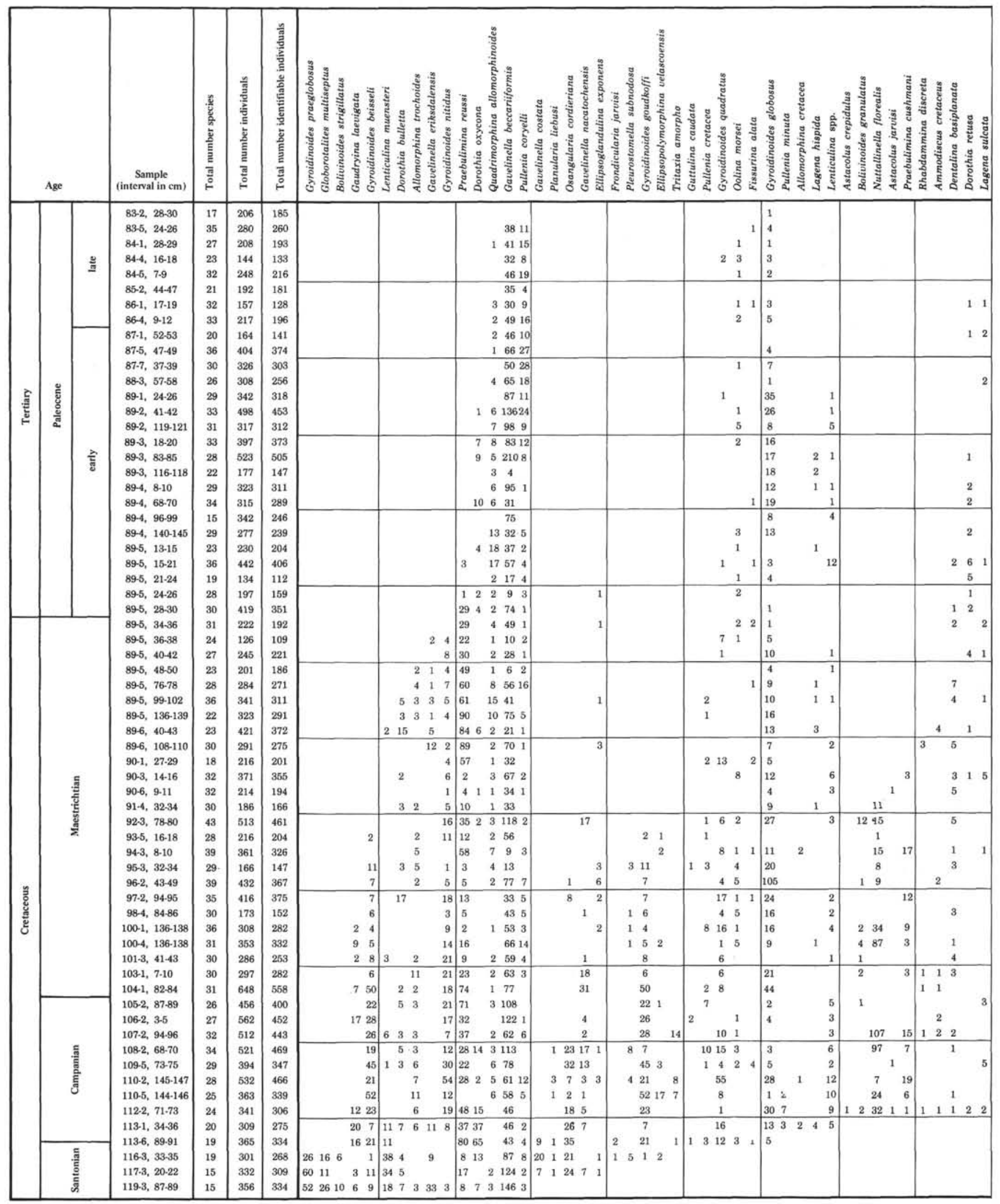




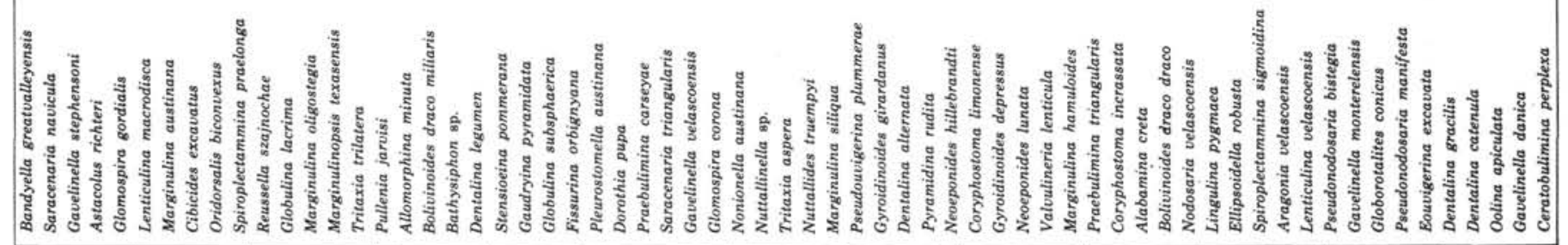

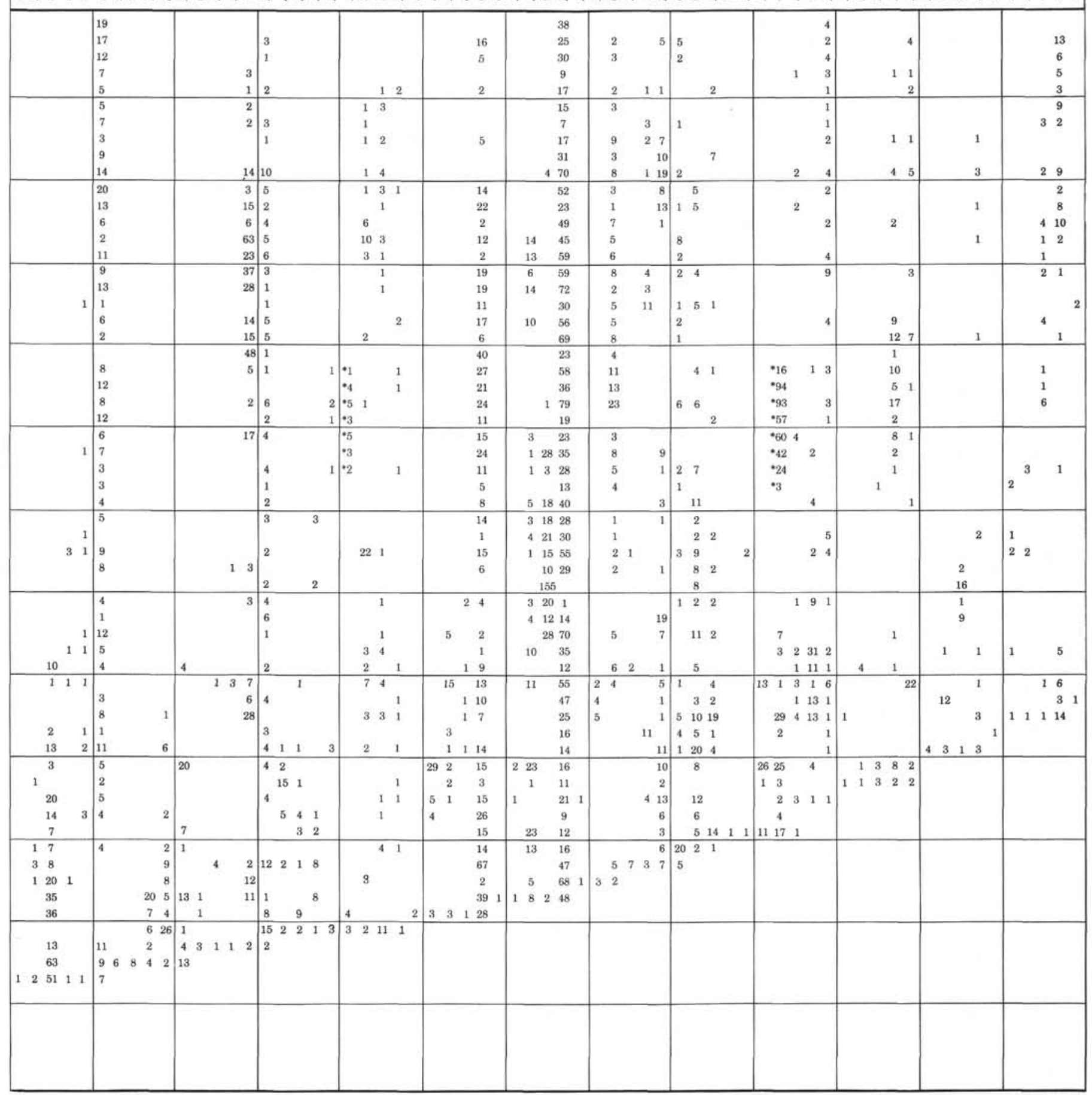


Appendix. (Continued).

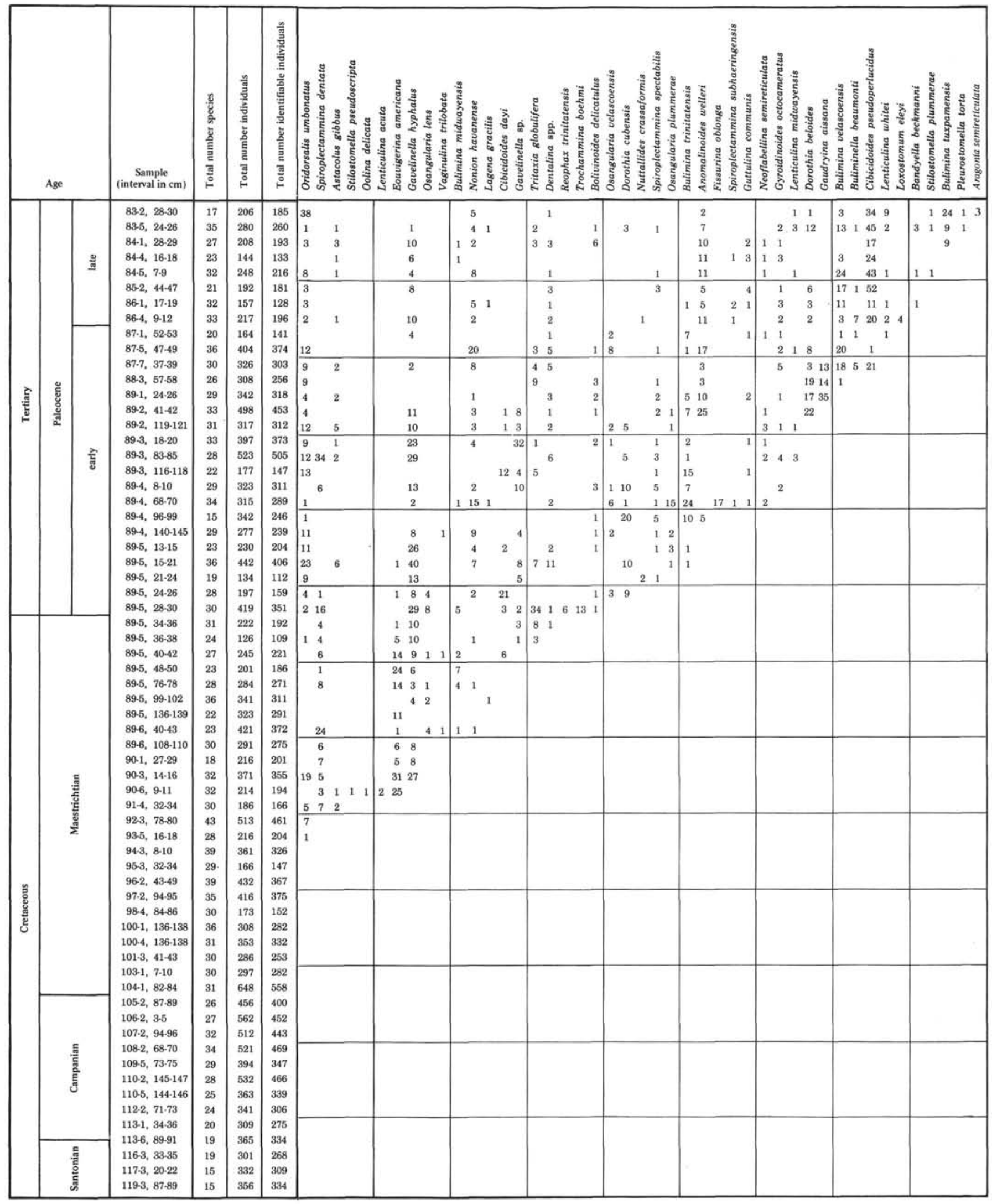




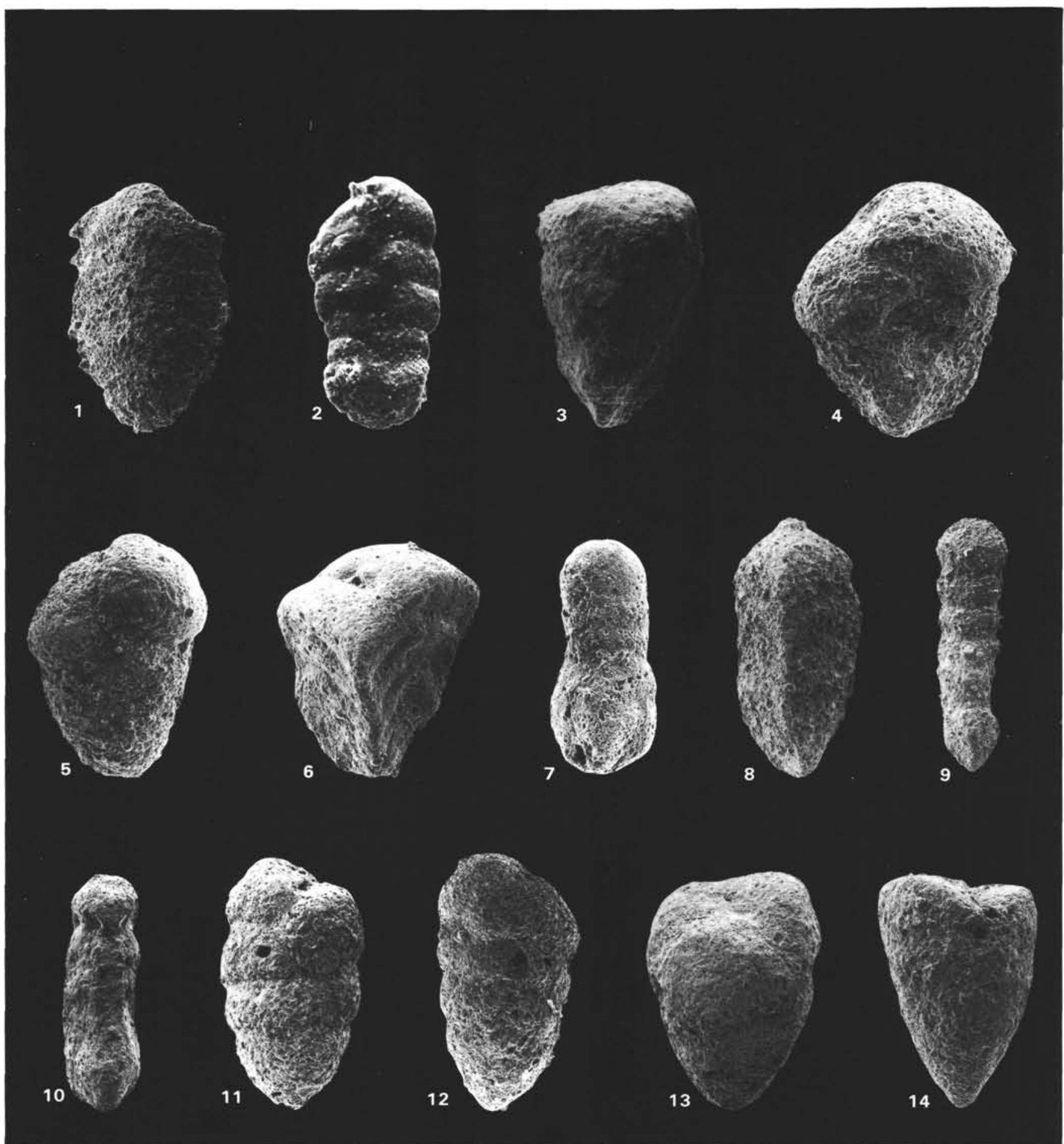

Plate 1. 1. Spiroplectammina dentata (Alth), Sample 516F-89-3, 83-85 cm, $\times 72$. 2. S. spectabilis (Grzybowski), Sample $516 \mathrm{~F}-83-5,24-26 \mathrm{~cm}$, $\times 144$. 3. Gaudryina aissana ten Dam and Sigal, Sample $516 \mathrm{~F}-89-1,24-26 \mathrm{~cm}, \times 54 . \quad 4$. G. laevigata Franke, Sample $516 \mathrm{~F}-97-2,94-95 \mathrm{~cm}$, $\times 45$. 5. G. pupa (Reuss), Sample $516 \mathrm{~F}-100-1,136-138 \mathrm{~cm}, \times 36$. 6. G. pyramidata Cushman, Sample $516 \mathrm{~F}-89-2,41-42 \mathrm{~cm}, \times 162$. 7. Tritaxia amorpha (Cushman), Sample $516 \mathrm{~F}-107-2,94-96 \mathrm{~cm}, \times 48 . \quad 8 . T$. aspera (Cushman), Sample 516F-89-6, 40-43 cm, $\times 54.9 .7$. globulifera (ten Dam and Sigal), Sample $516 \mathrm{~F}-83-5,24-26 \mathrm{~cm}, \times 28$. 10. T. trilatera Cushman, Sample $516 \mathrm{~F}-89-2,119-121 \mathrm{~cm}, \times 48$. 11. Dorothia beloides von Hillebrandt, Sample $516 \mathrm{~F}-83-5,24-26 \mathrm{~cm}, \times 60$. 12. D. bulletta (Carsey), Sample $516 \mathrm{~F}-89-5,136-139 \mathrm{~cm}, \times 45$. 13. D. cubensis (Cushman and Bermudez), Sample 516F-83-5, 24-26 cm, $\times 48$. 14. D. oxycona (Reuss), Sample 516F-113-6, 89-91 cm, $\times 96$. 


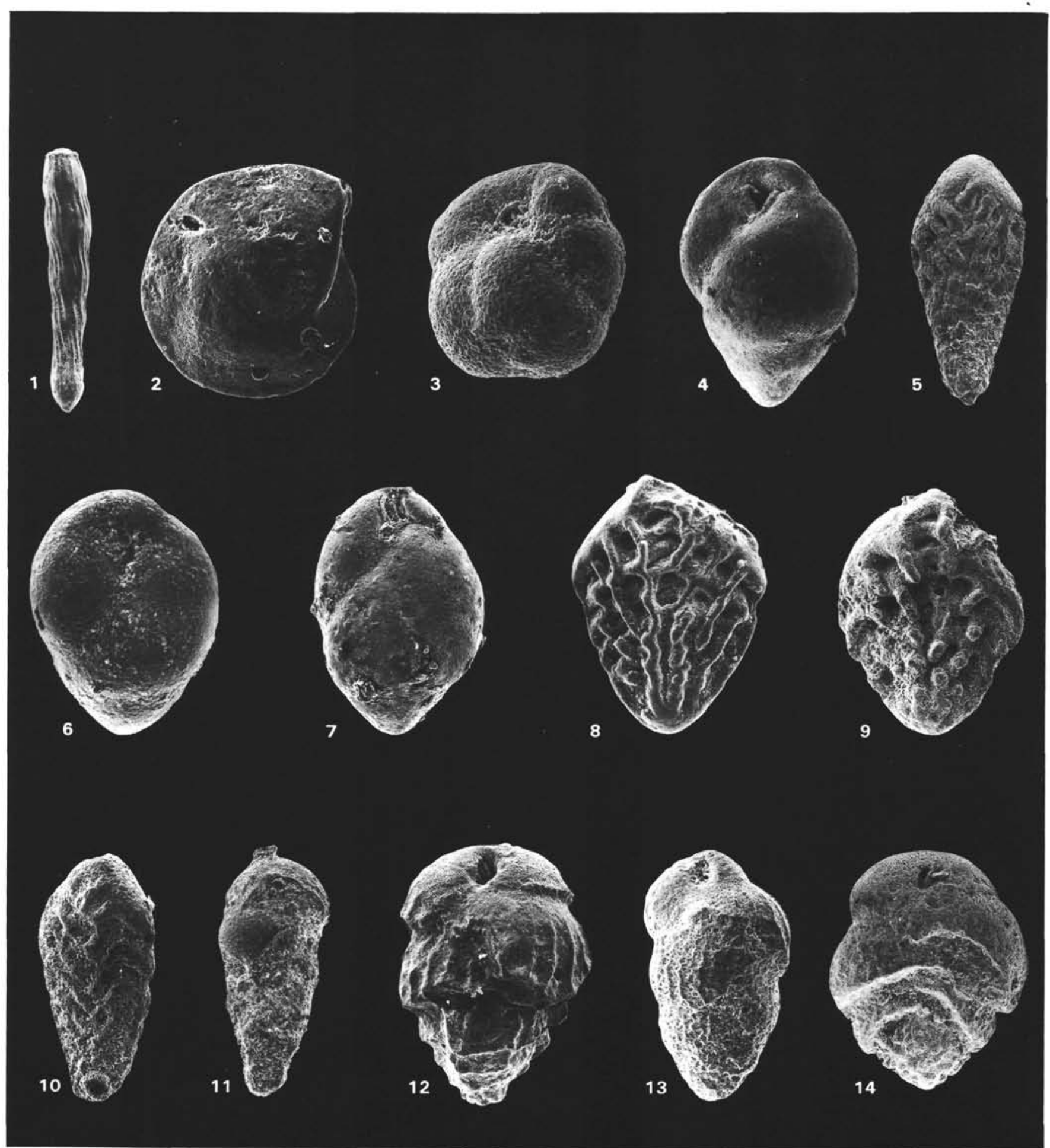

Plate 2. 1. Nodosaria velascoensis Cushman, Sample $516 \mathrm{~F}-89-3,18-20 \mathrm{~cm}, \times 45$. 2. Lenticulina macrodisca (Reuss), Sample $516 \mathrm{~F}-89-2,119-121$ $\mathrm{cm}, \times 120$. 3. Buliminella beaumonti Cushman and Renz, Sample $516 \mathrm{~F}-87-7,37-39 \mathrm{~cm}, \times 216$. 4. Bolivinoides delicatulus Cushman, Sample 516F-84-1, 28-29 cm, $\times 90$. 5-6, 11. Sample 516F-90-3, 14-16 cm, (5) Praebulimina carseyae (Plummer), $\times 120,(6) P$. cushmani (Sandidge), $\times 144$, (11) Eouvigerina americana Cushman, $\times 108$. 7. P. reussi (Morrow), Sample $516 \mathrm{~F}-89-5,99-102 \mathrm{~cm}, \times 108$. 8. Bolivinoides draco draco (Marsson), Sample 516F-91-4, 32-34 cm, $\times 108$. 9. B. draco miliaris Hiltermann and Koch, Sample 516F-101-3, 41-43 cm, $\times 144$. 10. B. granulatus Hofker, Sample $516 \mathrm{~F}-92-3,78-80 \mathrm{~cm}, \times 144$. 12. Bulimina trinitatensis Cushman and Jarvis, Sample $516 \mathrm{~F}-89-3$, $116-118 \mathrm{~cm}, \times 132$. 13. B. velascoensis (Cushman), Sample $516 \mathrm{~F}-84-5,7-9 \mathrm{~cm}, \times 96$. 14. Reussella szajnochae (Grzybowski), Sample 516F97-2, 94-95 cm, $\times 96$. 

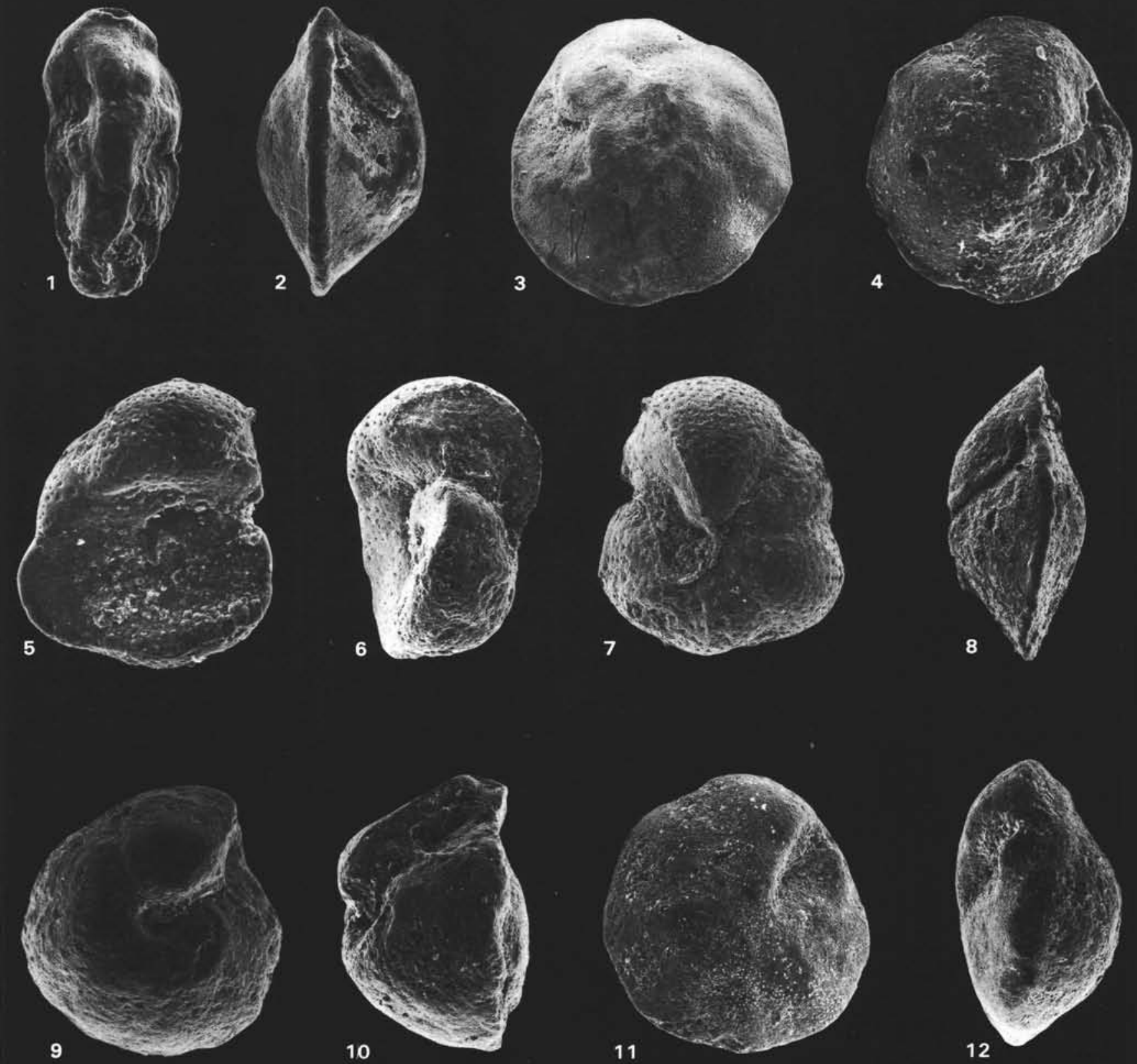

Plate 3. 1. Pseudouvigerina plummerae Cushman, Sample $516 \mathrm{~F}-93-5,16-18 \mathrm{~cm}, \times 96.2-3$. Nuttallides truempyi (Nuttall), Sample 516F-89-3, $18-20 \mathrm{~cm}, \times 162$, (2) peripheral view, (3) umbilical view. 4, 8. Nuttallinella florealis (White), Sample 516F-107-2, 94-96 cm, $\times 78,(4)$ umbilical view, (8) peripheral view. 5-7. Cibicides excavatus Brotzen, Sample $516 \mathrm{~F}-110-2,145-147 \mathrm{~cm}, \times 144$, (5) umbilical view, (6) peripheral view, (7) spiral view. 9-10. Nuttallinella sp., Sample 516F-94-3, 8-10 cm, $\times 198$, (9) umbilical view, (10) peripheral view. 11-12. Neoeponides hillebrandti Fisher, Sample 516F-87-5, 47-49 cm, $\times 162$, (11) umbilical view, (12) peripheral view. 

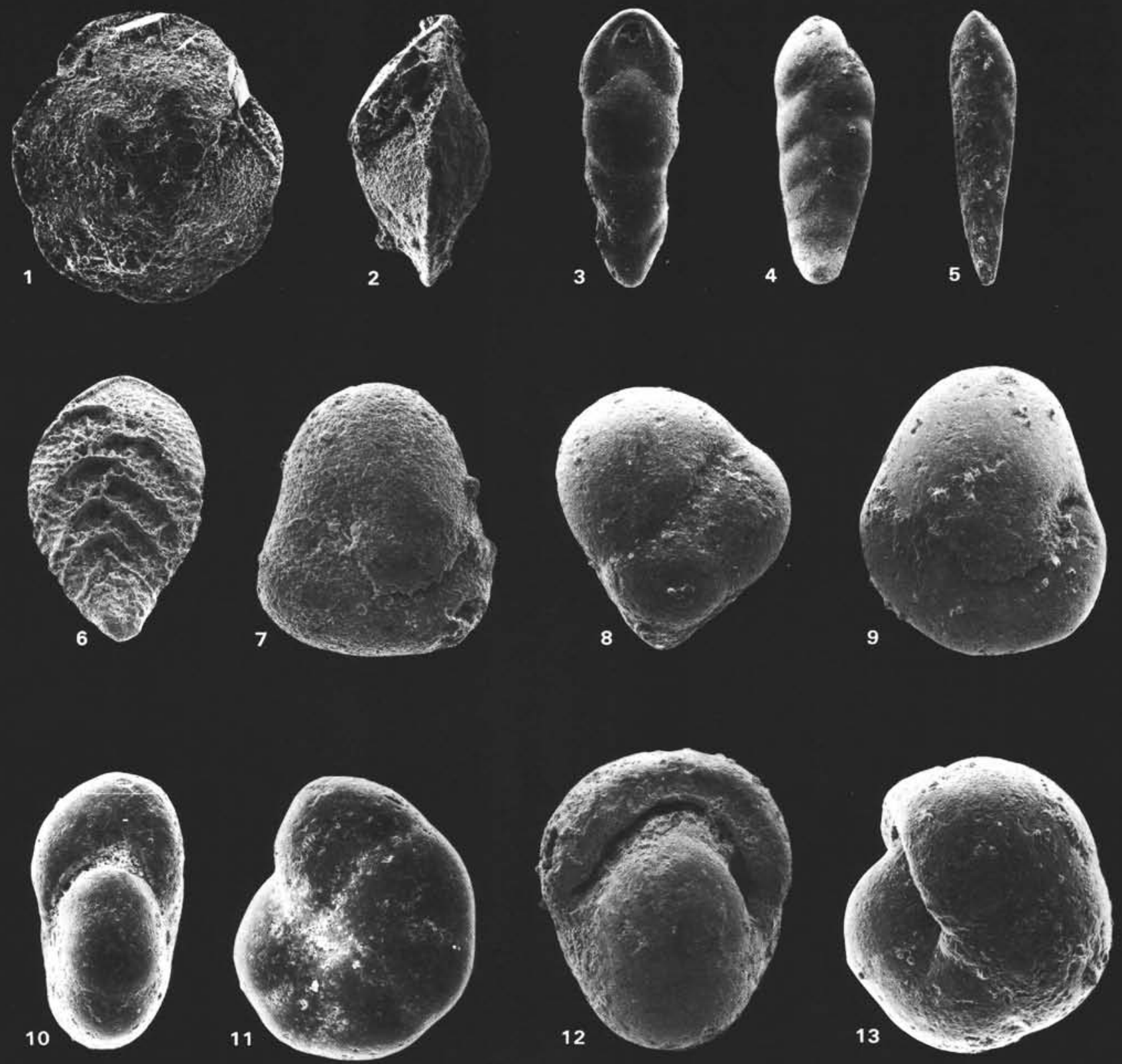

Plate 4. 1-2. Neoeponides lunata Brotzen, Sample 516F-87-1, 52-53 cm, $\times 144$, (1) umbilical view, (2) peripheral view. 3. Pleurostomella subnodosa Reuss, Sample $516 \mathrm{~F}-107-2,94-96 \mathrm{~cm}, \times 48$. 4. Coryphostoma incrassata Reuss, Sample $516 \mathrm{~F}-94-3,8-10 \mathrm{~cm}, \times 48$. 5. Coryphostoma limonense (Cushman), Sample 516F-89-2, 41-42 cm, $\times 72$. 6. Aragonia velascoensis (Cushman), Sample 516F-97-2, 94-95 cm, $\times 96$. 7. Allomorphina minuta Cushman, Sample $516 \mathrm{~F}-98-4,84-86 \mathrm{~cm}, \times 162$. 8. A. trochoides (Reuss), Sample $516 \mathrm{~F}-110-2,145-147 \mathrm{~cm}, \times 132$. 9 . Quadrimorphina allomorphinoides (Reuss), Sample 516F-89-5, 99-102 cm, $\times 90.10-11$. Nonion havanense Cushman and Bermudez, Sample $516 \mathrm{~F}-87-7,37-39 \mathrm{~cm}, \times 144,(10)$ apertural view, (11) side view. 12-13. Pullenia cretacea Cushman, Sample $516 \mathrm{~F}-108-2,68-70 \mathrm{~cm}, \times 120,(12)$ apertural view, (13) side view. 

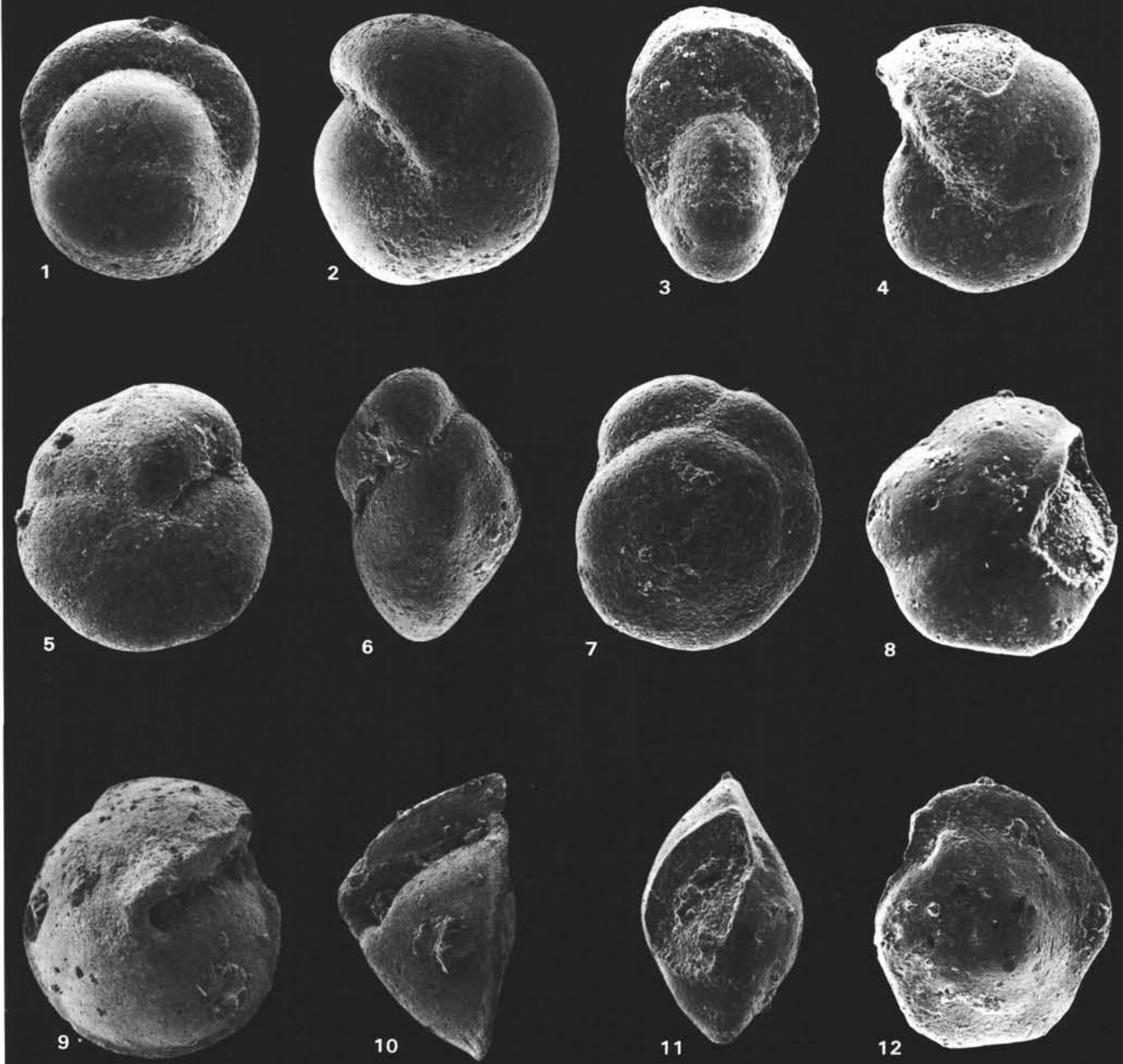

Plate 5. 1-2. Pullenia coryelli White, Sample $516 \mathrm{~F}-87-5,47-49 \mathrm{~cm}, \times 120$, (1) apertural view, (2) side view. 3-4. Pullenia jarvisi Cushman, Sample 516F-89-4, 140-145 cm, $\times 180$, (3) apertural view, (4) side view. 5-7. Alabamina creta (Finlay), Sample 516F-90-6, 9-11 cm, $\times 180,(5)$ umbilical view, (6) peripheral view, (7) spiral view. 8, 11-12. Oridorsalis biconvexus (Marie), Sample 516F-106-2, 3-5 cm, $\times 162,(8)$ umbilical view, (11) peripheral view, (12) spiral view. 9-10. Globorotalites conicus (Carsey), Sample 516F-89-6, 40-43 cm, $\times 78$, (9) umbilical view, (10) peripheral view. 


\section{H. DAILEY}
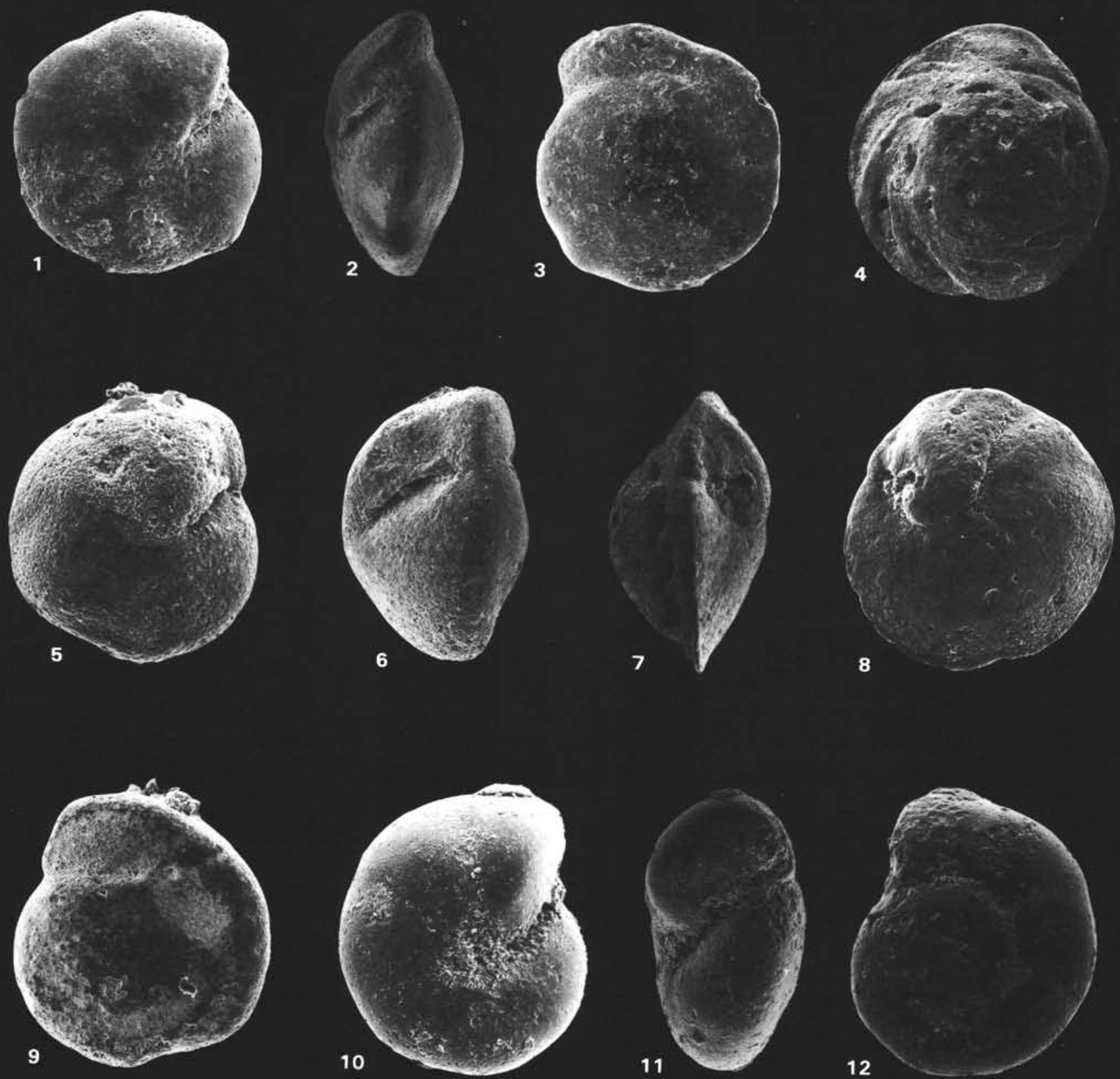

Plate 6. 1-3. Oridorsalis umbonatus (Reuss), Sample 516F-89-3, 83-85 cm, $\times 108$, (1) umbilical view, (2) peripheral view, (3) spiral view. 4, 7-8. Osangularia cordieriana (d'Orbigny), Sample $516 \mathrm{~F}-97-2,94-95 \mathrm{~cm}, \times 78$, (4) spiral view, (7) umbilical view, (8) peripheral view. 5-6, 9. Gyroidinoides beisseli (White), Sample 516F-103-1, 7-10 cm, $\times 120,(5)$ umbilical view, (6) peripheral view, (9) spiral view. 10-12. Gyroidinoides depressus (Alth), Sample 516F-88-3, 57-58 cm, $\times 144$, (10) umbilical view, (11) peripheral view, (12) spiral view. 

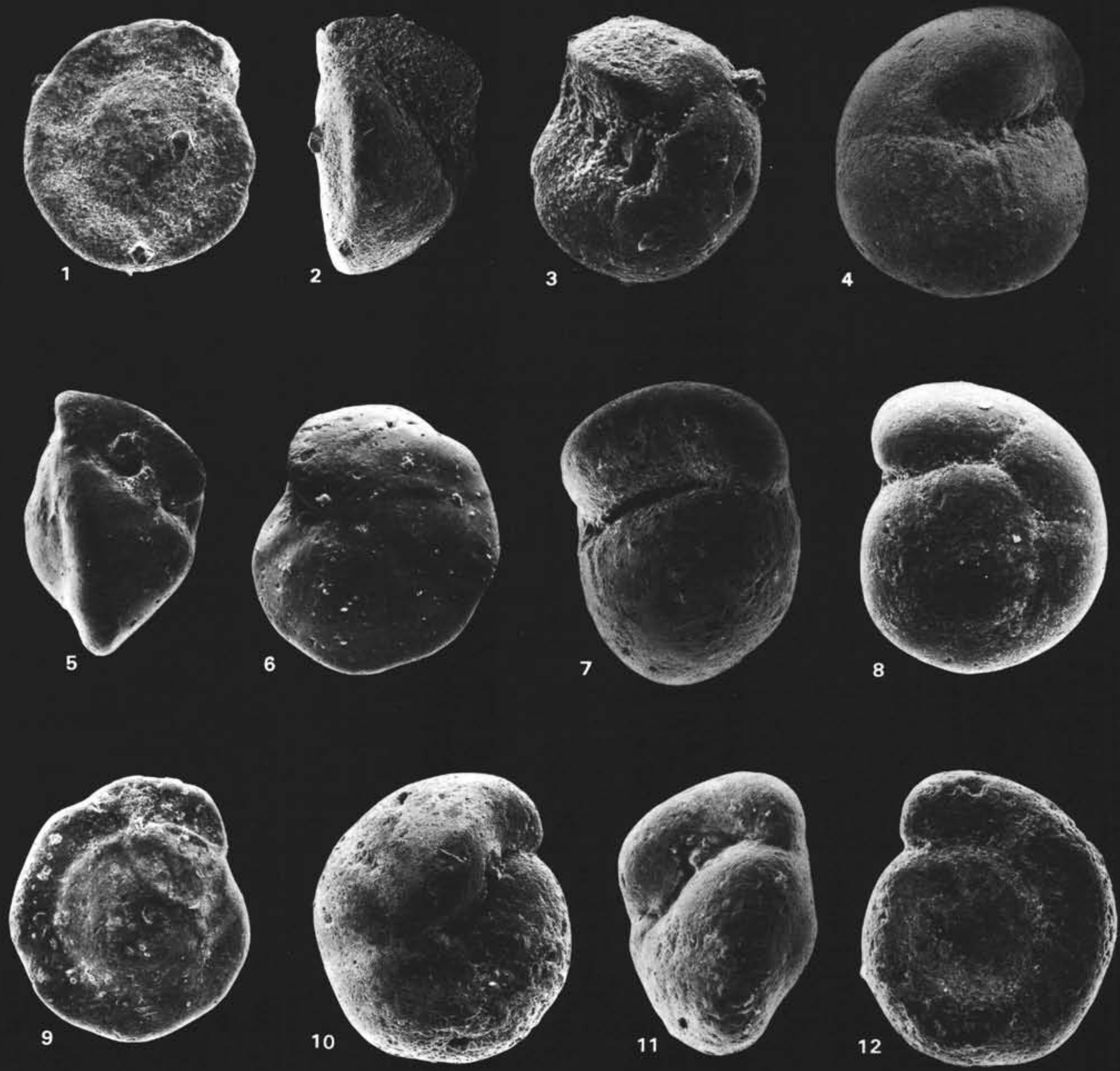

Plate 7. 1-3. Gyroidinoides girardanus (Reuss), Sample 516F-91-4, 32-34 cm, $\times 162$, (1) spiral view, (2) peripheral view, (3) umbilical view. 4, 7-8. G. globosus (Hagenow), Sample $516 \mathrm{~F}-92-3,78-80 \mathrm{~cm}, \times 144,(4)$ umbilical view, (7) peripheral view, (8) spiral view. 5-6, 9. G. goudkoffi (Trujillo), Sample 516F-106-2, 3-5 cm, $\times 108$, (5) peripheral view, (6) umbilical view, (9) spiral view. 10-12. G. nitidus (Reuss), Sample $516 \mathrm{~F}-97-2,94-55 \mathrm{~cm}, \times 162$, (10) umbilical view, (11) peripheral view, (12) spiral view. 

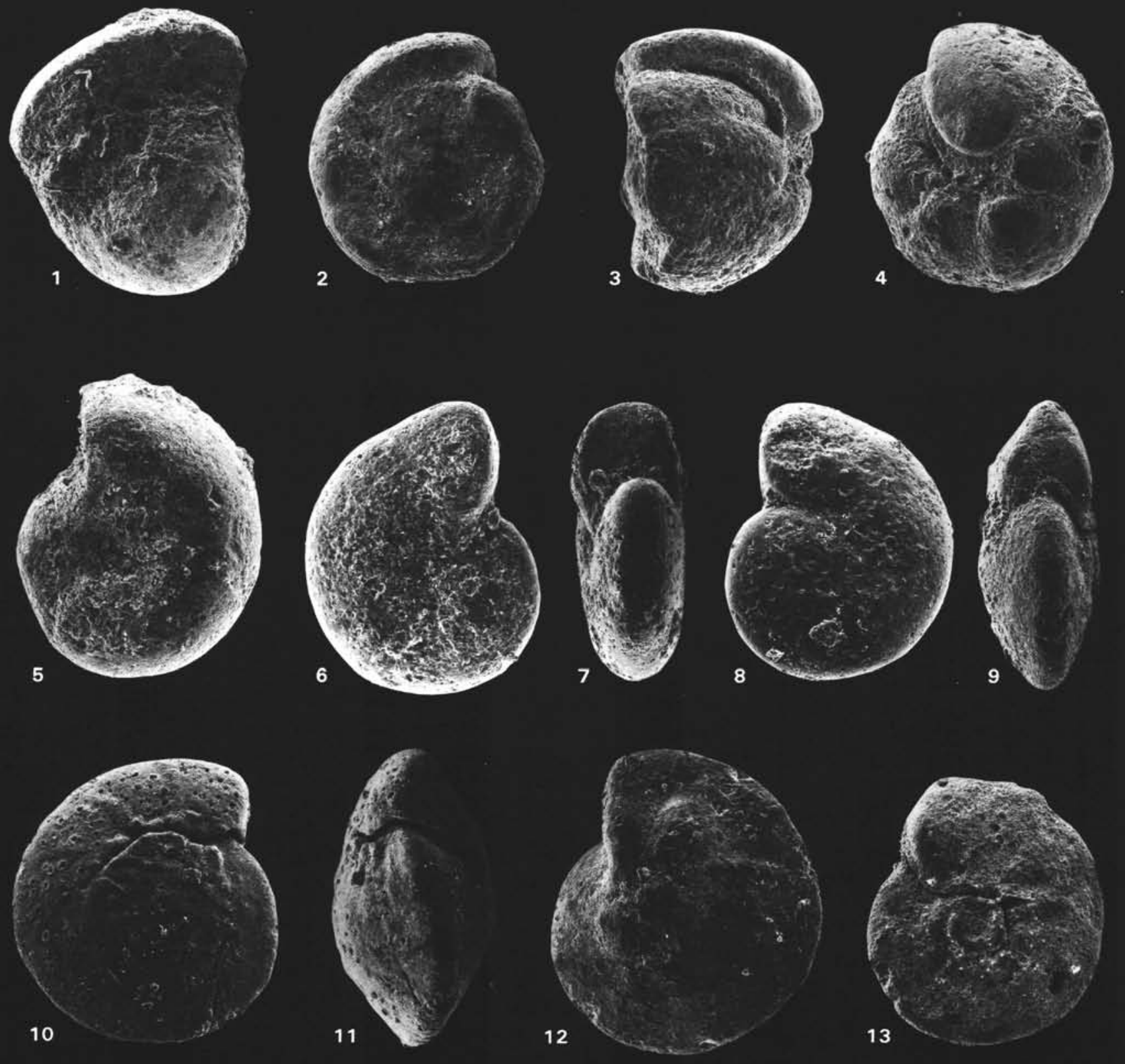

Plate 8. 1, 5. Gyroidinoides praeglobosus (Brotzen), Sample 516F-117-3, 20-22 cm, $\times 120$, (1) peripheral view, (5) spiral view. 2-4. G. quadratus (Cushman and Church), Sample 516F-97-2, 94-95 cm, $\times 108$, (2) spiral view, (3) peripheral view, (4) umbilical view. 6-8. Anomalinoides welleri (Plummer), Sample 516F-89-2, 41-42 cm, $\times 132$, (6) spiral view, (7) peripheral view, (8) umbilical view. 9, 13. Gavelinella monterelensis (Marie), Sample 516F-93-5, 16-18 cm, $\times 162$, (9) peripheral view, (13) umbilical view. 10-12. Cibicidoides pseudoperlucidus (Bykova), Sample $516 \mathrm{~F}-86-4,9-12 \mathrm{~cm}, \times 108,(10)$ spiral view, (11) peripheral view, (12) umbilical view. 


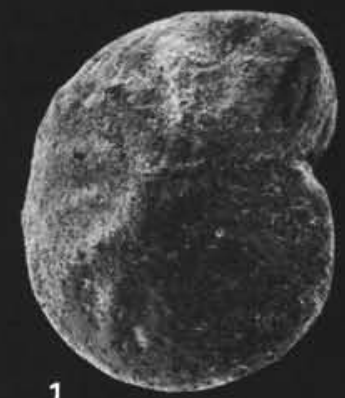

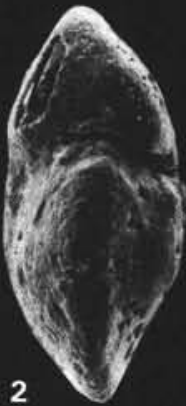
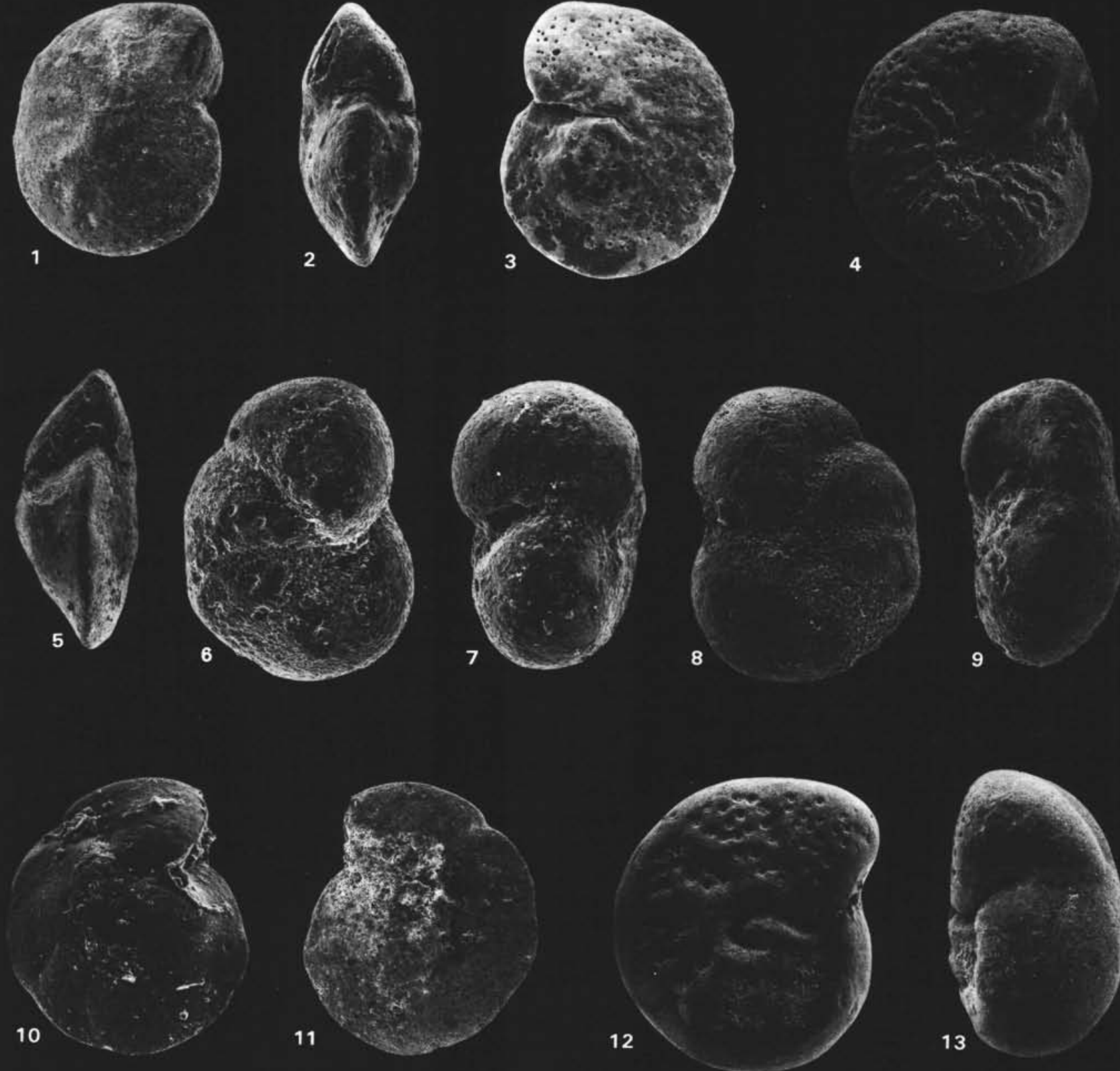

Plate 9. 1-3. Cibicidoides dayi (White), Sample $516 \mathrm{~F}-89-6,40-43 \mathrm{~cm}, \times 108$, (1) spiral view, (2) peripheral view, (3) umbilical view. 4, 9. Gavelinella beccariiformis (White), Sample 516F-88-3, 57-58 cm, $\times 96$, (4) umbilical view, (9) peripheral view. 5, 10-11. G. eriksdalensis (Brotzen), Sample 516F-89-6, 108-110 cm, $\times 78$, (5) peripheral view, (10) spiral view, (11) umbilical view. 6-8. G. danica Brotzen, Sample 516F-83-5, 24-26 cm, $\times 162$, (6) umbilical view, (7) peripheral view, (8) spiral view. 12-13. G. velascoensis (Cushman), Sample 516F-89-3, 18-20 cm, $\times 90$, (12) umbilical view, (13) peripheral view. 

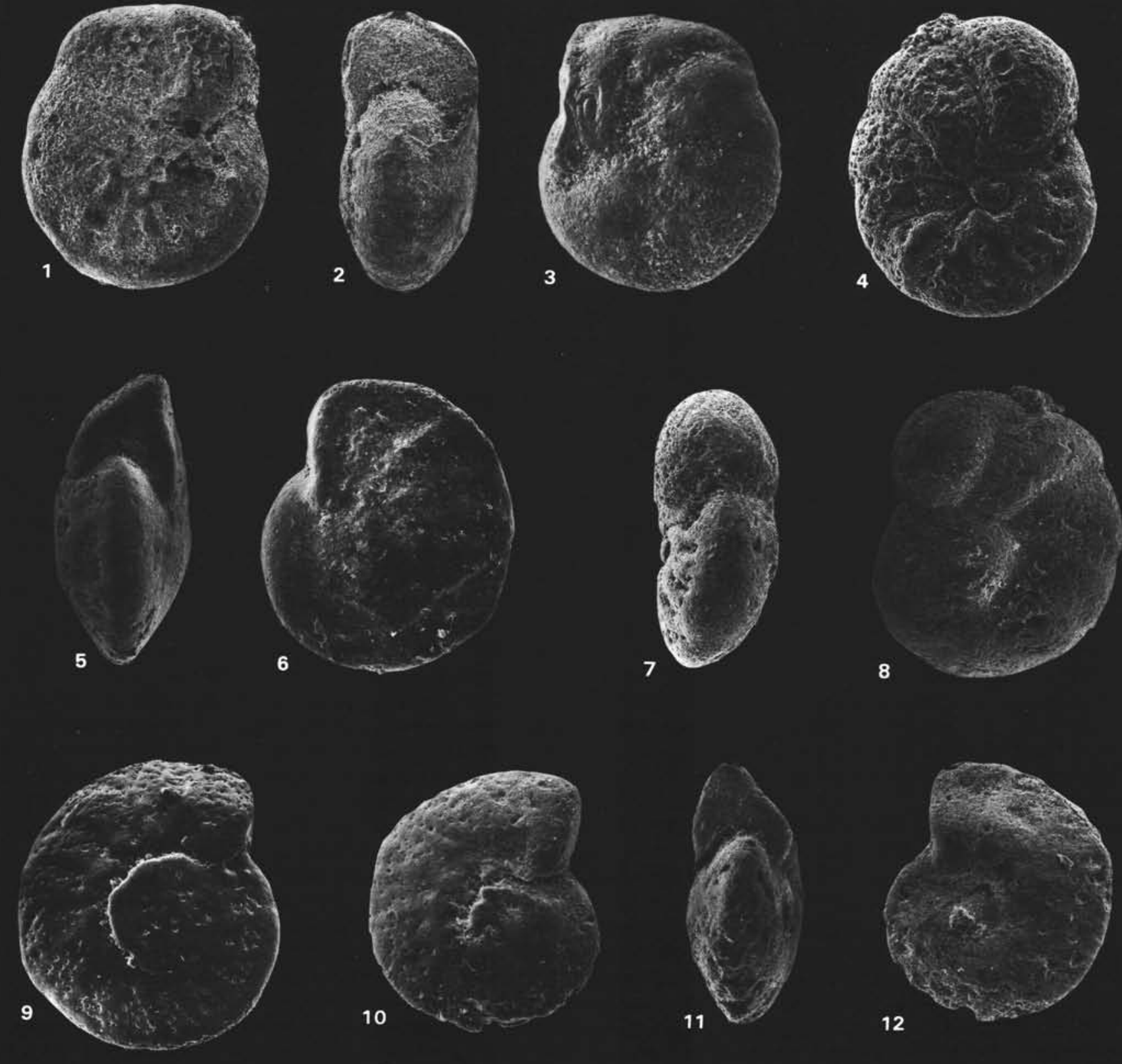

Plate 10. 1-3. Gavelinella hyphalus (Fisher), Sample 516F-85-2, 44-47 cm, $\times 78$, (1) umbilical view, (2) peripheral view, (3) spiral view. 4, 7-8. G. nacatochensis (Cushman), Sample 516F-109-5, 73-75 cm, $\times 132$, (4) umbilical view, (7) peripheral view, (8) spiral view. 5-6, 9. G. stephensoni (Cushman), Sample 516F-91-4, 32-34 cm, $\times 72$, (5) peripheral view, (6) spiral view, (9) umbilical view. 10-12. G. sp., Sample 516F-89-2, 119-121 cm, $\times 132$, (10) umbilical view, (11) peripheral view, (12) spiral view. 